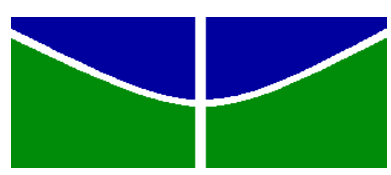

Universidade de Brasília (UNB)

Faculdade de Economia, Administração, Contabilidade e Ciência da Informação e Documentação (FACE).

Programa de Pós-Graduação em Administração - PPGA III Curso de Especialização em Gestão de Pessoas

SATISFAÇÃO DE CLIENTES

Autor(a): VALDECIR NUNES DOS SANTOS

Orientador: Professora Dra Jacqueline de Sá Leitão

Brasília-DF, 13 de Junho de 2008. 
Universidade de Brasília (UNB)

Faculdade de Economia, Administração, Contabilidade e Ciência da Informação e Documentação (FACE). Programa de Pós-Graduação em Administração - PPGA III Curso de Especialização em Gestão de Pessoas

\section{SATISFAÇÃO DE CLIENTES}

Monografia apresentada à
Universidade de Brasília (UNB),
para obtenção do certificado de
pós-graduação em Administração
- PPGA, do III Curso de
Especialização em Gestão de
Pessoas.

Autor (a): VALDECIR NUNES DOS SANTOS

Orientador: Professora Dra Jacqueline de Sá Leitão 


\section{DEDICATÓRIA}

Dedico esta Monografia a todas as pessoas das quais passaram em minha vida até agora, a todos os que tiveram o seu grau de influência em minhas atitudes.

Aproveito também, para estender a minha família, em especial, que são pessoas que tiveram caminhando ao meu lado, que sem a ajuda delas não seria possível à conclusão deste trabalho. 


\section{AGRADECIMENTOS}

Agradeço a Deus por estar me protegendo, ajudando e orientando a seguir os meus ideais e, principalmente por estar me dando força para sempre buscar novos e melhores objetivos.

A orientadora (o) Profa Orientadora Dra Jacqueline de Sá Leitão.

Pela realização deste trabalho o qual sem sua importante orientação não teria sido possível a sua conclusão.

A toda a minha família, amigos e colegas pelo enorme apoio durante estes anos.

E a todos os demais que, de alguma forma contribuíram na elaboração desta monografia.

Meu muito obrigado a todos! 


\section{LISTA DE QUADRO}

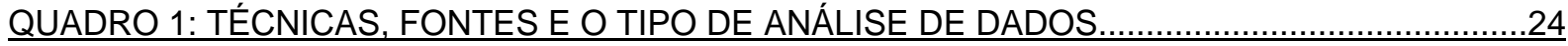




\section{LISTA DE GRÁFICOS}

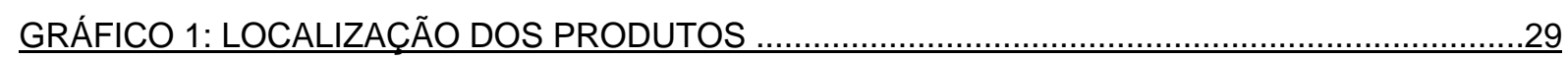

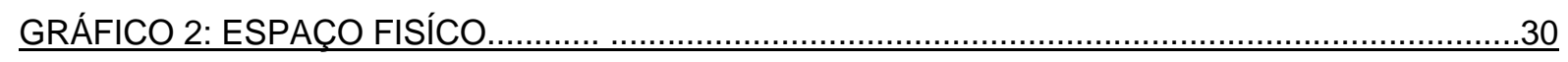

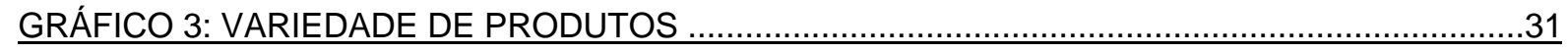

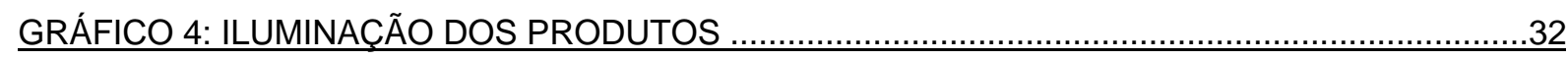

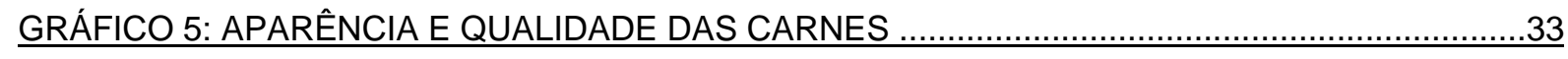

GRÁFICO 6: VALIDADE DOS PRODUTOS NÃO-PERECÍVEIS …............................................34

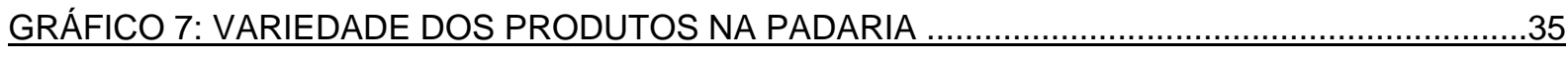

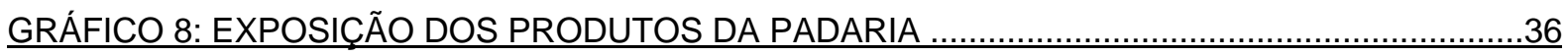

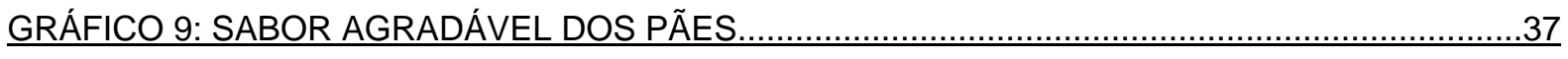

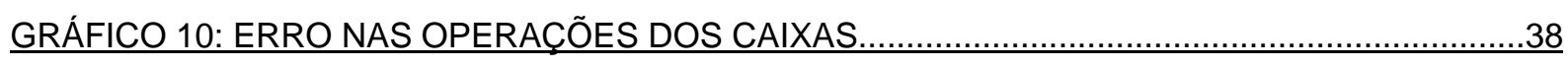




\section{LISTA DE TABELAS}

TABELA 1: QUESTIONÁRIO APLICADO NO MERCADO TRIUNFO ……………............................44 


\section{LISTA DE SIGLAS}

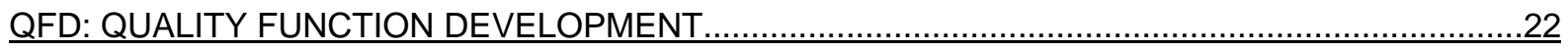




\section{SUMÁRIO}

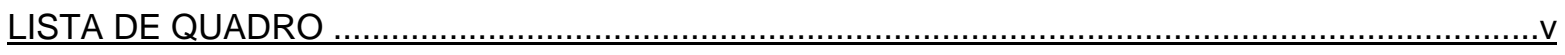

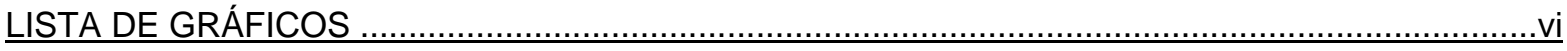

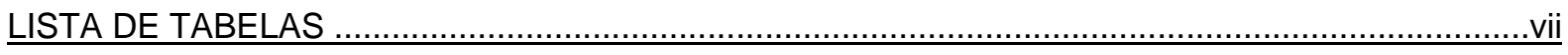

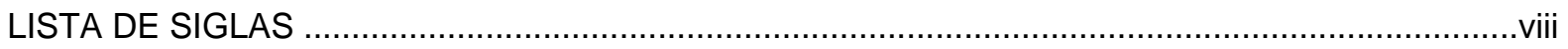

1-INTRODUÇÃ

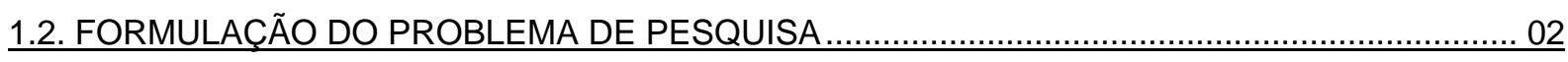

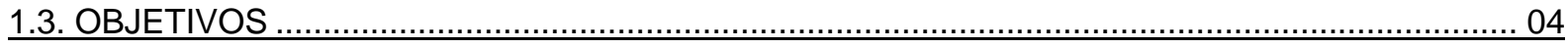

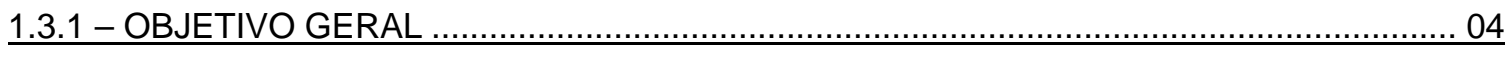

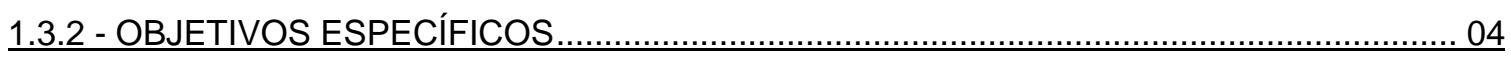

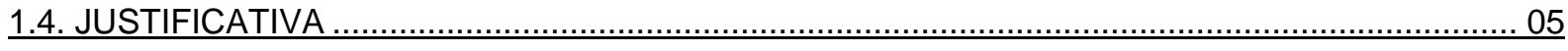

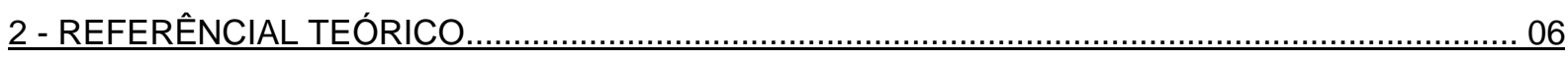

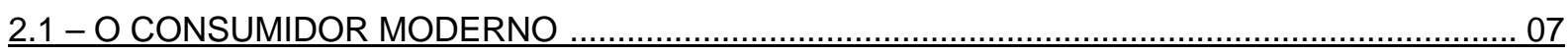

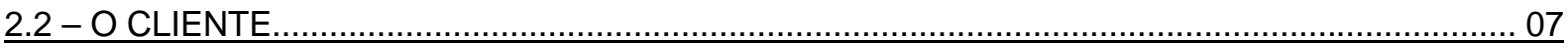

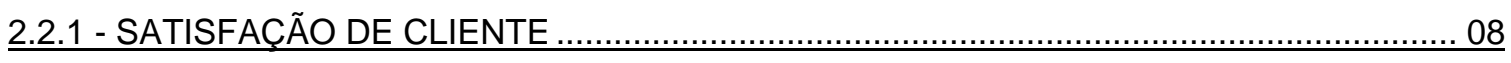

2.2.2 - DEFINIÇÃO DE VALOR E DE SATISFAÇÃO PARA O CLIENTE …………...................... 09

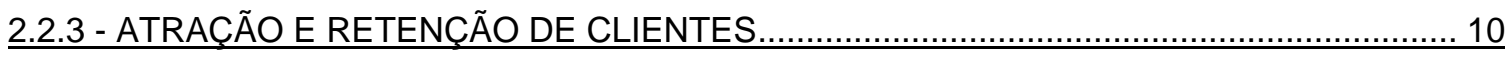

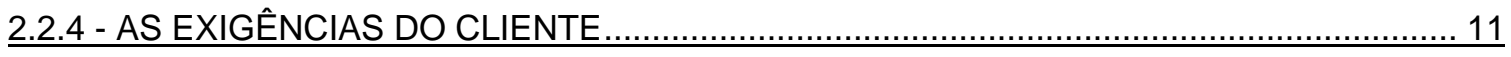

2.2.5 - DETERMINACCÃO DAS NECESSIDADES DO CLIENTE ……….................................. 12

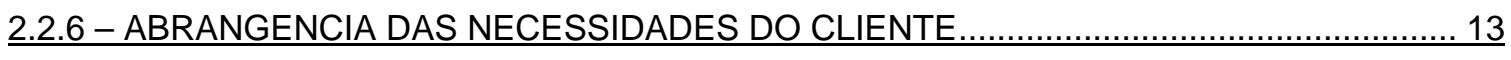

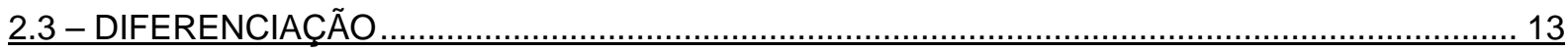

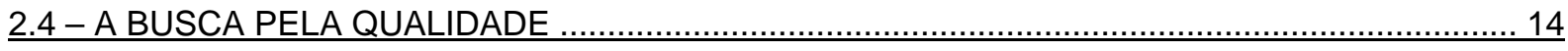

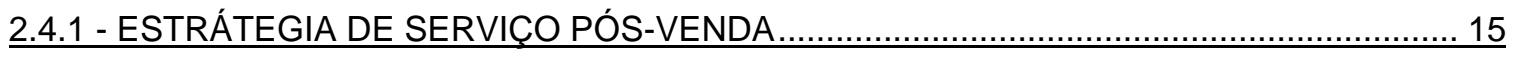

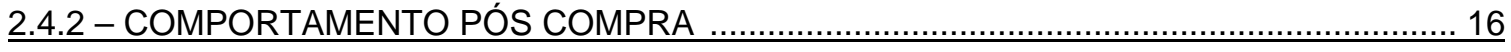

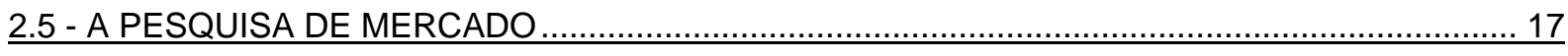

2.5.1 - OS VERDADEIROS CLIENTES DA PESQUISA DE MERCADO ……............................ 17

2.5.2- QUEM FAZ A PESQUISA DE MERCADO E ONDE ELA É FEITA? ................................ 18

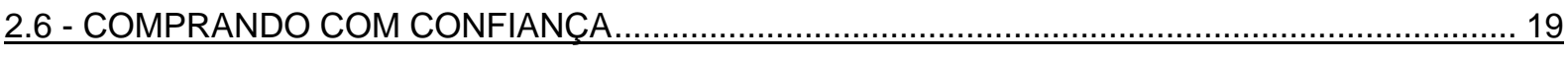

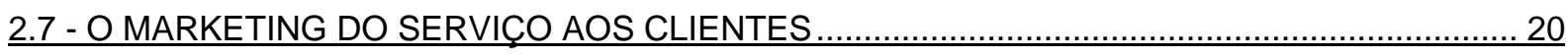

2.7.1 - O SIGNIFICADO DA PERCEPČ̃̃O, REACCÃO E CONFIABILIDADE DO CLIENTE.........21

2.7.2 - TEORIA CLÁSSICA DA MEDIÇÃO …………………………………………….... 22

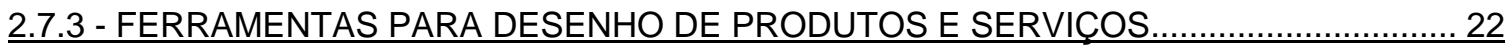

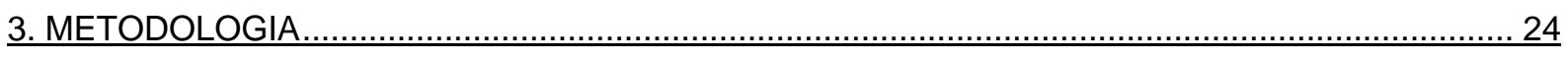

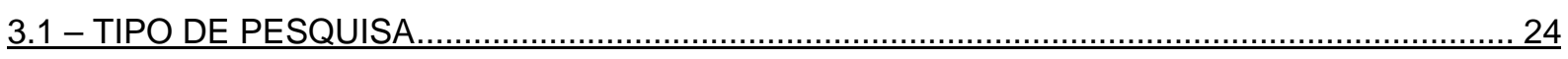

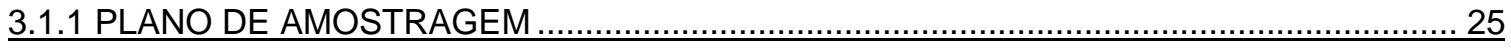

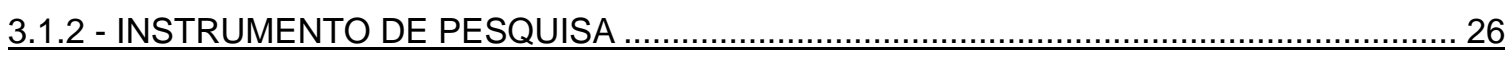

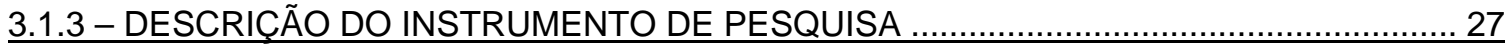

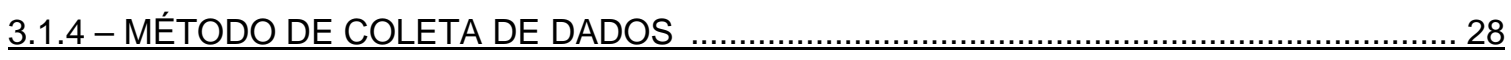

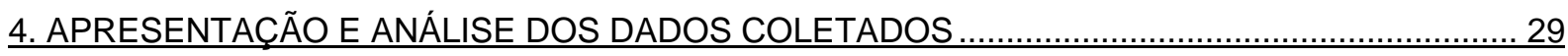




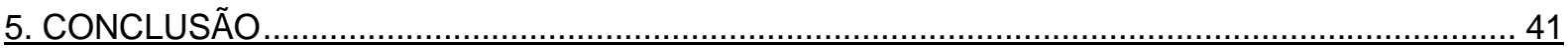

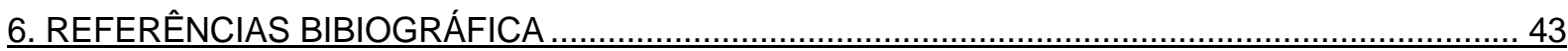

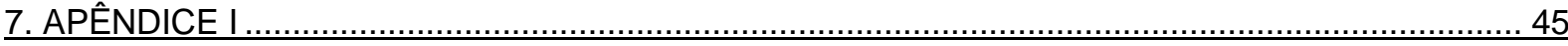

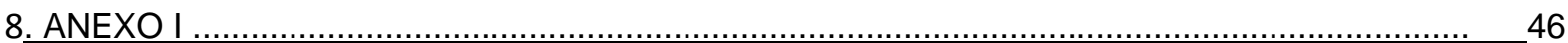




\section{RESUMO}

Realizou-se um estudo continuo de interação com os clientes, que permitiu estabelecer os objetivos da empresa, além de orientar o melhor aproveitamento dos recursos utilizados pela mesma. A satisfação é o ponto chave para o sucesso de qualquer empresa, buscando sempre atender a necessidade e qualidade dos serviços oferecidos aos seus clientes. O objetivo desta pesquisa foi desenvolver e avaliar o grau de satisfação dos clientes do mercado localizado na cidade satélite de Brasília-DF, em Vicente Pires, através de aplicação de questionários. Em uma base teórica, foram evidenciados os principais autores que define a satisfação como sentimento de prazer ou desapontamento, tanto com os serviços ou com o produto adquirido. Este estudo apresentou uma pesquisa quantitativa realizada através de perguntas estruturada fechadas, para medir o grau de satisfação dos serviços, produtos e qualidade de atendimento. Na conclusão, são apresentadas as considerações finais sobre a realização da pesquisa e as sugestões decorrentes dos resultados alcançados.

Palavras-chaves: Satisfação; Cliente; Qualidade. 


\section{1 - INTRODUÇÃO}

As questões de satisfação de clientes surgem do próprio conceito de Marketing, que busca a adequação entre o que é oferecido pela empresa e o que os clientes necessitam ou desejam.

A necessidade de um bom relacionamento entre a empresa e seu ambiente externo fica cada vez mais evidente com a globalização, pois as mesmas procuram se estruturar, para buscar uma adequação de seus custos juntamente com a qualificação perfeita e com isso obter uma maior qualidade nos seus produtos e serviços.

As ações de Marketing de uma organização devem ser permeadas com medidas que favoreçam e aumentem a satisfação do cliente, pois através de uma avaliação positiva, a empresa pode garantir ou, no mínimo, caminhar para um posicionamento adequado e lucrativo no mercado em que está inserida.

Por outro lado, se as empresas não incorporarem a satisfação de seus clientes como uma questão importante de Marketing, ela correrá o risco de perder tempo, dinheiro, imagem e credibilidade organizacional investindo na direção errada, valorizando questões que não são percebidas como valor agregado pelo seu mercado-alvo, desenvolvendo neste, um grau negativo de satisfação.

Com o objetivo de fidelizar e abrir oportunidades de expansão em um mercado no qual a competição é medida pela capacidade de absorção às mudanças e às informações, e a alma da empresa é o cliente, o relacionamento entre a empresa e o cliente demonstra uma evolução do pensamento mercadológico que precisa ter o apoio e a participação de todos na empresa.

O maior desafio é obter um diferencial competitivo que conquiste novos clientes e mantenha os já existentes de forma que eles não migrem para a concorrência. Assim a empresa trabalha voltada para o cliente, estabelecendo uma relação forte, gerando lucros e tornando-se mais competitiva.

A satisfação dos clientes é uma forma das empresas se manter no mercado a partir da conquista e fidelização de seus parceiros comerciais, por isso o tema satisfação ganhou maior importância no contexto da administração de empresas. 
Ao iniciar este estudo o objetivo foi identificar o grau de satisfação dos clientes do Mercado TRIUNFO, buscando avaliar como se encontra a empresa no mercado, a partir da visão dos próprios clientes.

\subsection{FORMULAÇÃO DO PROBLEMA DE PESQUISA}

Uma das questões de sobrevivência hoje no mercado é que o cliente sempre tem a razão e está sempre em primeiro lugar. Apesar desta frase ser bem conhecida, ela exprime uma postura indispensável para que qualquer organização alcance seus objetivos.

O objetivo comum a todas as empresas é de fornecer soluções para as necessidades de seus clientes, e seu sucesso resultará com a satisfação dos mesmos.

Os estudos sobre satisfação de clientes na administração são um dos aspectos prioritários na área de gestão, influenciando todos os processos da empresa.

Levando em consideração que o tema tem sua importância para retroalimentação e controle de uma empresa sob o ponto de vista do cliente (MARCHETTI, 2001, p. 57), diz que existe uma lacuna nesse aspecto em uma microempresa específica (objeto do estudo de caso), o projeto de pesquisa pretende medir o grau de satisfação de clientes nesta microempresa de gêneros alimentícios.

As empresas utilizam-se de várias ferramentas, para reter e captar novos clientes, uma tarefa que exige muita estratégia para quem quer se manter no mercado e liderar seu segmento, servir como referência para seus concorrentes. Porém, as organizações têm que trabalhar e administrar seus recursos que estão cada vez mais escassos, para atingir um excelente nível de satisfação e eficácia.

Mas para isso é necessário ter um ótimo planejamento para atingir seus resultados, até porque a organização tem um compromisso com seus clientes internos e externos, onde um dos principais objetivos é manter um bom relacionamento com fornecedores, colaboradores e clientes, oferecendo o melhor atendimento e produto do mercado.

É preciso que as empresas compreendam que o cliente insatisfeito espalha informações negativas, e dessa maneira a imagem da organização é prejudicada, por isso, a satisfação dos clientes é um importante instrumento de marketing, que 
pode ser usado pelos administradores como forma de tornar mais competitiva a empresa no mercado.

O problema que foi levantado nesta monografia diz respeito à satisfação dos clientes que não é uma opção e sim uma questão de sobrevivência para qualquer empresa. Portanto questiona-se até que ponto o mercado Triunfo atende às necessidades dos seus clientes, isto é, os mesmos estão satisfeitos com a empresa? 


\subsection{OBJETIVOS}

\subsection{1 - OBJETIVO GERAL}

Medir o grau de satisfação dos clientes de uma empresa do ramo de produtos alimentícios.

\subsection{2 - OBJETIVOS ESPECÍFICOS}

- Identificar na literatura as características e diversidade de abordagens sobre o conceito satisfação de clientes,

- Identificar a percepção de clientes da empresa sobre temas relativos a atuação da mesma;

- Estimular o comprometimento da gerência em comunicar aos funcionários a Missão e a Visão da empresa, seus valores e suas metas para alcançar, assim todos compartilham da real existência da empresa.

- Levantar as expectativas dos clientes, quanto aos serviços prestados pela empresa. 


\subsection{JUSTIFICATIVA}

A proposta de pesquisa que se apresentou justificou-se por alguns de seus aspectos, no que diz respeito ao tema satisfação de clientes, cuja manifestação é tópico de estudo na administração, configurando-se como interdisciplinar entre as áreas de marketing, planejamento estratégico e gestão organizacional.

A complexidade das características, atribuições e direcionamentos dos estudos de satisfação de clientes, bem como suas controvérsias e avaliações, são encontrados em estudos e pontos de vista teóricos de autores como, Barabba, (1992) que reconhece que na administração moderna existem clientes tanto dentro como fora da empresa.

Portanto, esse estudo justificou-se pela necessidade de se abordar na prática as teorias de satisfação de clientes adotadas geralmente em grandes empresas, aplicando-se também as empresas de pequeno porte.

A satisfação dos clientes é alcançada a partir de diversas ações que as empresas precisam executar, assim, oferecer produtos e serviços de qualidade, além de preços e prazos que são alguns pontos que podem influenciar na satisfação. Dessa forma, o presente estudo foi desenvolvido com a meta de identificar a satisfação dos clientes do Mercado TRIUNFO.

A busca pela satisfação dos clientes e a oportunidade de desenvolver um estudo acadêmico na empresa, demonstrou o interesse do proprietário em compreender a importância de um diferencial nos produtos, atendimento, partindo do princípio de que somente permanecem no mercado as empresas que identificam as necessidades e desejos de seus clientes e oferecendo o que estes buscam, a preços acessíveis, bons produtos e qualidade no atendimento.

Foram utilizadas 10 (dez) questões para medir o grau de satisfação dos clientes, a partir da estrutura teórica deste trabalho procurou-se fazer um estudo direto com os clientes do Mercado Triunfo. 


\section{2 - REFERÊNCIAL TEÓRICO}

A indicação preliminar do referencial teórico da presente pesquisa constitui por meio do qual o seu problema é compreendido e investigado. Desse modo, conceitos e teorias de diferentes autores servirão para compor o referencial teórico que norteará tanto a forma como o problema que será observado quanto o delineamento da abordagem e dos instrumentos metodológicos a serem utilizados.

A definição de Kotler (1998, p. 53) para satisfação é: "[...] o sentimento de prazer ou de desapontamento resultante da comparação do desempenho esperado pelo produto (ou resultado) em relação às expectativas da pessoa".

Sobre a satisfação dos consumidores é interessante avaliar que esta: [...] depende do desempenho do produto percebido com relação ao valor relativo às expectativas do comprador. Se o desempenho faz jus às expectativas, o comprador fica satisfeito, se excede a expectativa ele fica encantado. As companhias voltadas para marketing desviam-se do seu caminho para manter seus clientes satisfeitos. Clientes satisfeitos repetem suas compras e falam aos outros sobre suas boas experiências com o produto. A chave é equilibrar as expectativas do cliente com o desempenho da empresa. As empresas inteligentes têm como meta encantar os clientes, prometendo somente o que podem oferecer e depois oferecendo mais do que prometeram (KOTLER e ARMSTRONG, 1999, p. 6).

Em linhas gerais, a satisfação de clientes pode ser entendida com facilidade na compra de um produto de qualidade com preço compatível. No caso de um mini mercado, vários fatores influenciam, como a localização próxima a sua residência, a facilidade de acesso sem engarrafamentos e sem grandes filas nos caixas, produtos com preços acessíveis.

Tendo em vista essas questões, considera-se que a satisfação de clientes possui características próprias que devem ser avaliadas. O cliente satisfeito torna-se 
fiel. De acordo com Broydrick, (1997), ninguém vende seu produto ou serviço tão eficientemente quanto os seus clientes satisfeitos.

Por isso, procurar conhecer o ramo de atividade, o tipo de clientela e suas necessidades são fundamentais para se manter no mercado, onde a concorrência a cada dia que passa ganha mais espaço no mercado em qualquer ramo de atividade.

\section{1 - O CONSUMIDOR MODERNO}

De acordo com Kotler e Armstrong (2003), o consumidor moderno busca constantemente novos produtos e serviços, neste sentido, é preciso que as organizações acompanhem as mudanças desse novo mercado e ofereçam um atendimento de qualidade, causando satisfação aos clientes e se fortalecendo perante a concorrência.

Porém muitos fatores devem ser considerados para que a organização possa ter mais competência, independente de seu porte, sendo que neste sentido sempre é preciso trabalhar a qualidade dos serviços e do atendimento. $\mathrm{Na}$ compreensão de Chiavenato (2004, p. 15) "as organizações são criadas para produzir bens ou serviços e que os mesmos terão que satisfazer uma clientela". A competitividade nas organizações ganhou maior relevância nas discussões políticas e neste contexto a administração passou a ser avaliada sob uma nova ótica, como esclarece Chiavenato (2004 p. 96).

Neste sentido, entende-se que o desafio das empresas será a busca por formas de desenvolver um ambiente de trabalho produtivo, alcançando assim suas metas, seus objetivos, buscando a satisfação dos clientes que é o principal resultado da atividade organizacional.

\section{2 - O CLIENTE}

Os clientes buscam cada dia mais, bons produtos, serviços e atendimento que os satisfaçam, para isso é preciso conhecer o mercado em que a empresa está inserida e saber por meio de pesquisas e demais instrumentos de comunicação seus anseios e necessidades. A satisfação deve ser um processo contínuo, pois os clientes sempre procuram informações sobre o produto ao entrar na loja, por isso é 
importante, que os funcionários tenham conhecimento da sua atividade, de modo que possam satisfazer de forma rápida e eficaz as dúvidas dos clientes, conquistando-o e fidelizando-o.

O cliente deve ser tratado com respeito e dedicação, até porque de acordo com ZULKE apud RANGELI (1994, p. 26) "as pessoas contam suas experiências ruins para dez outras; as experiências positivas são contadas para apenas cinco".

Isto se faz concluir que a empresa deve estar sempre preocupada com o serviço prestado no dia-a-dia, pois os aspectos negativos são divulgados de forma ainda mais rápida que os positivos, neste sentido a empresa deve estar preparada para satisfazer os clientes.

Segundo Frencese e Pirto (1993) concentrar a atenção no cliente significa fazer três coisas:

- Entender as tendências do cliente;

- Dominar as informações sobre o cliente;

- Aprender a aplicar esses conhecimentos ao mundo real das estratégias de consumo.

Segundo Godri (1994, p. 17) "propaganda é apenas 1\% do processo de Marketing, o contato do dia-a-dia é o que realmente importa". Dessa forma, os clientes devem ser identificados, compreendidos e trabalhados, buscando a satisfação e a fidelização dos mesmos como instrumentos de fortalecimento no mercado. Pois o marketing boca a boca pode ser de uma forma tanto positiva como negativa, dependendo somente de como foi passada a imagem da empresa para o mercado de consumidores.

\subsection{1 - SATISFAÇÃO DE CLIENTE}

A satisfação é um dos principais elementos capazes de fidelizar um cliente. Dessa forma, as empresas devem buscar uma forma de estreitar a relação com seus clientes, tornando-os parceiros comerciais. O cliente satisfeito é o elemento essencial para o sucesso de uma empresa.

A satisfação do cliente é o grau de felicidade experimentada por ele. Ela é produzida por toda uma organização, por todos os departamentos, todas as funções e todas as pessoas. Entre os clientes se incluem compradores externos de bens e 
serviços, fornecedores, comunidade local, funcionários, gerentes e supervisores (e acionistas, se a organização for de capital aberto).

O bom atendimento aliado à satisfação é o aspecto que faz o cliente retornar, por isso, o cliente tem que ser o motivo maior, pois estes quando satisfeitos são mais do que simples consumidores ou clientes, mas sim, parceiros comerciais e advogados que defendem a empresa e fazem propaganda para amigos e familiares.

A organização deve estar comprometida em criar um cliente satisfeito, porque segundo Kotler (1998), "a satisfação é um sentimento resultante da comprovação do desempenho esperado pelo produto em relação às expectativas da pessoa".

Ressalta-se que um consumidor fica satisfeito quando as ofertas (produtos, serviços e atendimento) oferecidas a eles ultrapassam as suas expectativas, assim, Kotler (1998, p. 53) define que: "satisfação é o sentimento de prazer ou de desapontamento resultante da comparação do desempenho esperado pelo produto (ou resultado) em relação às expectativas da pessoa".

Relacionamentos com clientes são construídos com o tempo,... Clientes antigos sempre oferecem um potencial de lucros maior do que o de novos clientes, eles também estão propensos a adquirir outros produtos e serviços da empresa, e muitas vezes geram propaganda de boca favorável. (MARTINS \&. CARDOSO 2000 P. 41).

Ao ficar satisfeito o consumidor cria laços com a empresa e afinidade emocional, resultando na lealdade do mesmo, pois o relacionamento de cliente leal para com a empresa é de fundamental importância para a sua sobrevivência no mercado.

Satisfação do cliente é, portanto, uma dimensão que expressa o grau de satisfação, a partir das suas percepções em relação ao desempenho de um conjunto de fatores avaliados que superam ou ficam além do esperado. É evidente que várias são as conceituações sobre satisfação de clientes, mais todas as conceituações estão voltadas para um único objetivo: o resultado.

\subsection{2 - DEFINIÇÃO DE VALOR E DE SATISFAÇÃO PARA O CLIENTE}


Há mais de 35 anos, Peter Drucker, observou que a primeira tarefa de uma empresa é 'criar clientes'. Mas os clientes de hoje se deparam com um vasto universo de produtos, preços e fornecedores pelos quais podem optar. Mas como os clientes fazem suas escolhas?

Acreditamos que os clientes avaliam qual oferta proporciona maior valor, eles procuram sempre maximizar o valor, dentro dos limites impostos pelos custos envolvidos na procura e pelas limitações de conhecimento. Eles formam uma expectativa de valor e agem com base nela. A probabilidade de satisfação e repetição da compra depende se a oferta atende ou não a essa expectativa de valor. (KOTLER, 2000).

A satisfação dos clientes não é uma opção e sim uma questão de sobrevivência para qualquer empresa. Para satisfazer o cliente é necessário ter, primeiro, uma compreensão profunda de suas necessidades e, em seguida, possuir os processos de trabalho que possam, de forma efetiva e consistente, resolver essas necessidades. Para isso a empresa deverá traduzir essas necessidades em requisitos e cumprir esses requisitos, sempre, porque o cliente não exigirá menos.

Philip Crosby escreveu a seguinte metáfora: "Os relacionamentos de uma organização representam sua alma, a qualidade seu esqueleto e as finanças sua sangue". O objetivo principal de qualquer organização é a satisfação de seus clientes, sem seus clientes a organização não tem propósito, alias, nem existirá por muito tempo.

A satisfação dos clientes e a habilidade da empresa de obter lucros são variáveis interdependentes. Ao mesmo tempo os lucros são os resultados da eficiência com que a organização atende aos requisitos e expectativas de seus clientes, ao se obter bons lucros, automaticamente teremos a atração dos clientes e assim à retenção dos mesmos é evidente.

\subsection{3 - ATRAÇÃO E RETENÇÃO DE CLIENTES}

As necessidades de serviços dos clientes mudam, do mesmo modo que suas expectativas de como essas necessidades serão satisfeitas. As pesquisas, portanto, nunca podem oferecer um quadro totalmente estável. Walter (1991) Acredita que: "Mas importante, antes de planejar uma investida estratégica, é 
focalizar o mercado, e obter um registro das necessidades e expectativas dos clientes e de suas percepções quanto ao nosso desempenho atual". Subseqüência, você precisa ser capaz de fazer uma checagem de tempos em tempos para medir seu progresso e identificar tendências e mudanças que estejam ocorrendo.

Alguns fatores devem ser considerados no atendimento, como o fato de que quanto mais ágil, é fácil a transação para os clientes adquirem o produto. Assim, uma forma de conquistar os clientes é tentar evitar a burocracia, as empresas precisam trabalhar de forma a qualificar o ambiente e considerar a satisfação dos consumidores como ponto principal.

Os clientes gostam de ser chamados pelo nome, pois se sentem especiais, por isso, o vendedor tem que encantar o cliente, estabelecendo laços de amizade, com isso obtém a fidelidade do cliente, e a partir de diversas atividades, como a facilitação de entrega, cobrança, crediário, escolha, dentre outras vantagens que podem encantar o cliente. Eltz, (1994).

Os clientes anseiam por segurança, as empresas têm que mostrar que é seguro negociar com as mesmas, tende a ser honestas ao oferecer os produtos, evitando criar altas expectativas, mas procurando sempre fazer mais do que prometeu, como esclarece (ROBERT J. RAUSCHER apud DETZEL e DESATNICK 1995 p. 55).

A única maneira de provar serviços consistentes ao cliente é fazer com que cada funcionário focalize sua atenção na maneira com ele/ela afeta o cliente final e identifique maneiras para exceder consistentemente suas expectativas.

Ao mesmo tempo em que se devem exceder as expectativas, é importante ao realizar a venda para o cliente, elogiar a escolha feita, porém que este elogio seja feito com sinceridade, para surtir mais efeito diante do cliente, que terá mais confiança no vendedor e na empresa na qual adquiriu o produto.

O cliente é o principal elemento formador de uma empresa, é este o termômetro de análise, para saber se a mesma está tendo ou não sucesso com as suas vendas. A principal ferramenta que conquista todo e qualquer cliente é o atendimento, sendo que a qualidade deste é indiscutível para o resultado final, ou seja, a compra de um determinado produto. 
A palavra-chave da empresa é ser a solução para o cliente e não o problema para o mesmo, pois no mundo globalizado de hoje, os clientes estão cada vez mais exigentes e com menos tempo para esperar o atendimento em qualquer empresa.

\subsection{4 - AS EXIGÊNCIAS DO CLIENTE}

O que o cliente exige, é uma síntese harmoniosa entre a qualidade do atendimento que lhe oferecemos e sua aptidão a satisfazer as necessidades ou os desejos dele, o custo dos serviços e o valor que o cliente atribui a ele, o prazo de entrega ou as modalidades de colocar o serviço ou produto à sua disposição e a urgência de sua necessidade. A cada vez que não correspondemos corretamente a essas exigências, a cada vez que não existe adequação entre atendimento e expectativa, perde-se clientes e parcelas do mercado, portanto, receitas e margem de lucro (JOCOU, 1996).

Atrair e satisfazer, em um mercado cada vez mais competitivo é oferecer aos clientes serviços de valor em constante crescimento. Este valor deve ser apreciado em nível e em regularidade; o cliente sabe sempre medi-lo, pelo menos por comparação com o que a concorrência lhe oferece. Ele tem seus critérios de julgamento, que um fornecedor responsável não deve ignorar, nem desprezar. Estes critérios permitem-Ihe avaliar e comparar o que lhe dá valor de um produto ou de um serviço (JOCOU, 1996).

Os clientes de hoje são mais difíceis de agradar. São mais inteligentes mais conscientes com relação aos preços, mais exigentes, perdoam menos e são abordados por mais concorrentes com ofertas iguais ou melhores. Neste sentido, entende-se que o cliente fiel é aquele que está satisfeito com o atendimento e, que se torna parceiro comercial da empresa, devido ao grau de satisfação com as atividades executadas.

\subsection{5 - DETERMINAÇÃO DAS NECESSIDADES DO CLIENTE}

Geralmente avaliamos um produto ou serviço em termos de várias dimensões ou características. Por exemplo, depois de recebermos um serviço, podemos avaliar o seu fornecedor como rápido, sempre disponível quando dele 
precisamos, e desagradável. Segundo Hayes (2001) "estas descrições representam três aspectos do serviço: presteza, disponibilidade e profissionalismo, respectivamente. Estes são um subconjunto de todas as dimensões possíveis pelas quais um serviço pode ser descrito. A composição de todas elas descreve o produto ou serviço integral".

O cliente deve sempre ser colocado no centro das decisões, uma vez que ele é o eixo em torno do qual tudo deve girar, pois a organização existe, em primeiro lugar, para atender às suas necessidades.

Este é um objetivo permanente que pode ser alcançado pelas organizações através de procedimentos como:

- Comprometimento da equipe de trabalho;

- Estabelecimento de metas desafiadoras;

- Padronização de procedimentos;

- Capacitação das pessoas;

- Aprendizado organizacional;

- Reconhecimento e recompensa;

- Marketing de relacionamento;

- Elevado nível de atendimento ao cliente;

- Introdução de melhorias contínuas.

A adoção desses procedimentos pode aumentar o nível de retenção de clientes, garantindo melhores resultados através de experiências repetidas de consumo.

\subsection{6 - ABRANGÊNCIA DAS NECESSIDADES DO CLIENTE}

Segundo Hayes (2001). "as necessidades do cliente obtidas a partir das entrevistas devem definir de forma abrangente, a qualidade do serviço ou produto. Se uma categoria importante de necessidades do cliente for omitida durante as entrevistas iniciais, o questionário de satisfação do cliente resultante será deficiente para avaliar todas as necessidades. Em outras palavras, você será incapaz de avaliar a percepção de seus clientes acerca de um componente importante de seu serviço ou produto. Subseqüentemente, você não seria capaz de aperfeiçoar a 
satisfação total do cliente, por que você não sabe o motivo pelo qual seus clientes estão satisfeitos ou insatisfeitos".

Para que se possa saber qual o nível de abrangência de satisfação precisamos buscar saber sempre como está o conceito da empresa no mercado.

Para identificar as reais necessidades do cliente, é necessário fazer perguntas cujas respostas permitam identificar, não apenas suas necessidades, mas também suas expectativas e desejos.

\section{3 - DIFERENCIAÇÃO}

Diferenciação é o ato de desenvolver um conjunto de diferenças significativas para distinguir a oferta da empresa da oferta da concorrência. Kotler (2000).

As empresas de serviços freqüentemente reclamam da dificuldade de criar um diferencial para seus serviços. A desregulamentação de vários importantes setores de serviços, como comunicações, transportes, fornecimento de energia e bancos, gerou uma intensa concorrência de preços.

O sucesso das empresas de aviação que oferecem preços modestos é um bom exemplo de que muitos passageiros dão mais importância aos custos da viagem do que aos serviços oferecidos.

O sucesso contínuo da Charles Schwab nos serviços de corretagem de valores mostra que muitos clientes não se mostram leais às casas de corretagem mais tradicionais quando podem economizar dinheiro.

Quando os clientes vêem um serviço sendo razoavelmente homogêneo, passam a se preocupar menos com o fornecedor e mais com preço. Kotler, (2000).

A diferenciação de uma empresa é capacidade de ser percebida como diferente de seus concorrentes, em função de suas vantagens competitivas, seus produtos, preços e serviços.

\section{4 - A BUSCA PELA QUALIDADE}

A qualidade de um produto ou serviço pode ser olhada de duas ópticas: a do produtor e a do cliente. Do ponto de vista do produtor, a qualidade se associa à 
concepção e produção de um produto que vá ao encontro das necessidades do cliente. Do ponto de vista do cliente, a qualidade está associada ao valor e à utilidade reconhecidas ao produto, estando em alguns casos ligada ao preço.

Do ponto de vista dos clientes, a qualidade não é unidimensional. Quer dizer, os clientes não avaliam um produto tendo em conta apenas uma das suas características, mas sim de várias características. Por exemplo, a sua dimensão, cor, durabilidade, design, funções que desempenha, etc. Assim, a qualidade é um conceito multidimensional e é por isso que é mais difícil de definir. De tal forma, que pode ser difícil até para o cliente exprimir o que considera um produto de qualidade.

Para Martins \& Cardoso (2002), a qualidade no atendimento depende dos seguintes fatores:

$>$ Presteza: desejo real de colaborar com o cliente e de fornecer serviços com prontidão;

> Competência: capacitação dos recursos humanos e tecnológicos da empresa;

> Cortesia: educação, respeito, consideração e cordialidade do pessoal que lida com o cliente;

> Confiabilidade: capacidade de cumprir o prometido;

> Credibilidade: transmissão de confiança e honestidade no trato com o cliente;

$>$ Segurança: sigilo, confidencialidade nos negócios, segurança pessoal e do patrimônio;

> Facilidade de acesso aos fornecedores e aos produtos: inclusive facilidade de contato como o pessoal da empresa:

> Comunicação: manter o cliente informado, em linguagem compreensível, fornecendo instruções de uso adequados, manuais etc.

A qualidade e o serviço são os meios para atingir o fim, que é a satisfação e o regresso do cliente. $O$ objetivo da empresa não deve ser produzir um produto ou um serviço de qualidade ou fornecer um bom serviço ao cliente, mas deve sim criar um cliente satisfeito e leal, que vá ter sempre consigo. Portanto, dar um bom serviço de alta qualidade ao cliente, são os meios para atingir o fim principal.

\subsection{1 - ESTRÁTEGIA DE SERVIÇO PÓS-VENDA}


O atendimento ao cliente não se restringe apenas ao momento da compra, mas também o pós-venda, a empresa tem que utilizar processos de comunicação para saber a opinião do cliente em relação ao atendimento, produto e serviço adquirido, fortalecendo assim, a parceria empresa/cliente.

Precisamos sempre esta preocupada em saber como estão os serviços, se eles estão de acordo com as necessidades, para isso precisamos aferir como essa a empresa no mercado, com isso medimos o grau de satisfação dos clientes.

São várias as formas de aferir a satisfação do cliente, dentre as quais destacam-se: pesquisa de satisfação; caixas de sugestão; consultas para saber se os clientes indicariam os produtos ou serviços da empresa para seus amigos.

Melo (2003) apresenta vários fatores de satisfação de clientes que podem ser aferidos como, por exemplo:

a) Atendimento: cortesia, educação e atenção por parte de quem atende; rapidez com que é dada resposta a problemas, dúvidas e reclamações; solução dada aos problemas, dúvidas e reclamações; clareza das informações prestadas; interesse e boa vontade de quem atende para resolver problemas; atendimento realizado por telefone; atendimento pessoal.

b) Conta, cobrança e condições de pagamento: prazo entre a compra e o pagamento; existência de diferentes formas de pagamento; exatidão dos valores cobrados; quantidade de informações contidas na conta; número de contas com reclamações de erros.

c) Qualidade do produto ou serviço: qualidade intrínseca do produto ou serviço; regularidade na entrega ou na prestação do serviço; qualidade da embalagem;

d) Preço: preço cobrado pelo produto ou serviço; descontos concedidos; promoções;

e) Informações prestadas: clareza das informações prestadas; utilidade das informações; quantidade de informações prestadas;

f) Serviços de assistência: tempo para entrega do produto ou instalação do serviço; garantia; interesse e boa vontade dos técnicos; horário de entrega/atendimento.

Ao executar o atendimento, tem que se priorizar o vínculo humano, ou seja, primeiro o cliente, depois o lado comercial, lembrando sempre que cada cliente é único, que não há dois iguais e que de cada um depende a permanência da empresa no mercado. 


\subsubsection{COMPORTAMENTO PÓS-COMPRA}

A compra traz consigo três fatores relevantes para o comportamento do consumidor.Primeiro terá influência no seu comportamento de consumo futuro. Segundo poderá ocorrer o que Festinger denominou de dissonância pós-decisória. E, finalmente, o comportamento pode ser influenciado por expectativas não satisfeitas. Os aspectos de consumo conseqüente ou futuro podem ser vistos como uma necessidade de consumo correlato por implicarem despesas de instalação e uso e também o interesse e a necessidade em outros produtos e serviços correlatos. Gade, (1980) p 179.

A avaliação pós-compra, no sentido de se ela satisfaz as expectativas, se ela é reforçadora ou não, se implica outras aquisições, e se estas, por sua vez, são percebidas como reforçadoras, evidentemente ocorrerá com maior probabilidade quando se trata de uma compra após um processo decisório extenso do que após a compra compulsiva, quando se trata de produto ou serviço raramente adquiridos, ou mesmo, pela primeira vez, do que quando se trata de uma aquisição costumeira ou de produto conhecido. Gade (1980) p 180.

Infelizmente, constata-se que raramente os consumidores demonstram voluntariamente ao fornecedor do serviço sua insatisfação.

Este fato decorre de três fatores principais:

- Os funcionários de empresas de serviços não costumam favorecer reclamações, assumindo uma postura defensiva;

- Os consumidores geralmente não acreditam que a reclamação possa gerar algum resultado;

- Quando consumidor participa do processo do serviço, sente-se coresponsável por sua própria insatisfação, Gianesi (1996) p 73.

O comportamento do consumidor após a compra do serviço depende de seu grau de satisfação com o resultado, a satisfação é o principal resultado da atividade organizacional e está voltado para o comportamento do consumidor, em especial ao comportamento pós-compra, pois segundo Gianesi \& Correa (1996), quanto mais satisfeito com o serviço, maior será a probabilidade de repetição da compra. Outro efeito positivo é a possibilidade de recomendação do serviço a outros consumidores. Esta tese pode ser defendida com base no fato de o consumidor, como já foi 
discutido, percebe certo risco na compra de serviços, pela impossibilidade ou dificuldade de avaliá-lo antes da compra. Gianesi (1996) p 72.

\section{5 - A PESQUISA DE MERCADO}

\subsection{1 - OS VERDADEIROS CLIENTES DA PESQUISA DE MERCADO}

A administração moderna reconhece que existem clientes tanto dentro como fora da empresa. As pessoas envolvidas com um centro de consultas precisam considerar todas as áreas funcionais e todos os grupos dentro da organização como seus clientes ou fregueses. Este ponto de vista diverge de classificação mais restrita e comum, onde o departamento de pesquisas de mercado trata a função de marketing como seu único cliente importante.

É difícil alcançar esta perspectiva mais ampla quando a empresa não tem nenhum especialista em pesquisas e contrata sempre o serviço de terceiros. Mesmo quando existe uma equipe interna de pesquisa, essa perspectiva não é muito fácil.

Muitos pesquisadores de mercado estão estreitamente ligados às organizações de marketing e dispõem de pouco incentivos para desenvolver outros clientes. Além disso, as exigências feitas às equipes de pesquisa deixam-lhes pouco tempo para cultivar outros clientes. O problema é, muitas vezes, agravado pela resistência da função de marketing em compartilhar os dados de mercado. (BARABBA V. e GERALD ZALTMAN, 1992).

\subsection{2- QUEM FAZ A PESQUISA DE MERCADO E ONDE ELA É FEITA?}

A pesquisa de mercado envolve pessoas em todos os níveis e em todos os passos do movimento de um produto ou serviço desde a concepção até a venda. Algumas pessoas precisam fornecer informações; outras precisam usar essas informações.

Para usá-las com eficácia, os fornecedores precisam saber de que informações os usuários precisam. Da mesma forma, os usuários de informações precisam estender a utilidade e as limitações das informações coletadas. Tomando emprestado uma afirmação com freqüência usada na estatística, "É muito melhor 
uma resposta apropriada à pergunta certa que seja vaga, do que uma resposta exata à pergunta errada que possa ser precisa".(BARABBA V. e GERALD ZALTMAN, 1992).

A função da pesquisa de mercado é, na verdade, um negócio dentro do próprio negócio que precisa produzir, vender e entregar seu produto.

O produto é uma informação de mercado acurada e conveniente, produzida e entregue com bastante antecedência no ciclo de desenvolvimento do produto da empresa para auxiliar todo os envolvidos nos processos decisórios dentro da empresa.

A função da pesquisa de mercado tem mais probabilidade de contribuir para a rentabilidade, o que exige o fortalecimento de relações mais amplas com as outras funções da empresa, e o fornecimento de dados úteis e oportunos que descrevem a voz do mercado. (BARABBA V. e GERALD ZALTMAN, 1992).

Broydrick (1997), defende os seguintes pontos:

- Os clientes fiéis são mais lucrativos. Quando mais tempo eles permanecem fieis, mais você ganha. No Harvard Business Review, Frederick F. Reichheld e Earl Sasser Jr. fizeram um levantamento em quatro industrias distintas e descobriram que a fidelidade do cliente era a chave para a maior lucratividade. Por exemplo, a empresa típica de cartão de crédito gasta 51 dólares para conquistar um novo cliente. Só a partir do quinto ano é que a ela obtém um lucro anual com este cliente. Nos anos seguintes, o lucro começa a crescer.

- Os clientes fiéis se tornam sua força de vendas secretas. Ninguém vende seu produto ou serviço tão eficientemente quanto os seus clientes satisfeitos. A credibilidade que eles têm com seus amigos, vizinhos ou colegas de trabalho é inquestionável. Eles enviam clientes potenciais para você, dispensando o investimento excessivo em publicidade e marketing.

- Os clientes fiéis são uma valiosa fonte de informações. A maioria fica contente em dizer como você pode continuar a satisfazer suas necessidades. Eles podem ajudar a projetar os futuros produtos e serviços. O jornalista Michael Schrage diz que: "As empresas devem aprender que seus melhores clientes não são apenas aqueles que geram a maior parte dos lucros, mas 
também aqueles que trazem a inspiração para as melhores idéias e inovações".

- Os clientes fiéis não são tão sensíveis aos preços quanto os 'James Tyrones'. De acordo com a pesquisa de Reichheld e Sasser Jr., "Muitas pessoas pagarão mais para se hospedar em um hotel que conhecem ou se consultar com um medico em quem confiam evitando se arriscar com um concorrente menos caro". A experiência de nossos próprios clientes, incluindo Johnson \& Dix e Action Automation, sustentam esta opinião.

A função da pesquisa é pensar e agir com espírito empreendedor. Precisa reconhecer a necessidade de vender continuamente seus produtos. Pensando e agindo como função integrante do processo de tomada de decisão.

\section{6 - COMPRANDO COM CONFIANÇA}

Qualquer tipo de negócio pode 'beijar alguns sapos' para que os clientes não tenham de fazê-lo. Uma loja de ferramentas na vizinhança pode experimentar 30 modelos de furadeira elétrica e resolver vender apenas os três que apresentarem o melhor desempenho. Se o comprador quiser 30 opções, ele pode ir até a Home Quarters, a Builders Square ou a Home Depot. Achará maior variedade e talvez um preço mais baixo na 'superloja', mas pode acabar levando para casa um sapo em vez de um príncipe. Broydrick, (1997).

Ainda segundo Broydrick, (1997). O organizador de um congresso para uma empresa pode tentar se virar sozinho e esperar encontrar um ótimo conferencista para o seminário marcado para breve, ou pode telefonar para uma agência de conferencistas de alta qualidade e contar com eles para estreitar sua decisão de compra, apresentando-lhe apenas alguns excelentes profissionais para escolher. Pagará um pouco mais, mas a agência de conferencistas o recompensará proporcionando-Ihe mais tempo para dedicar a outros projetos importantes.

A empresa de encomendas postais Hámmacher-Schlemmer apresenta a seção "O melhor" em cada um de seus catálogos. Somente um modelo de CD player de cabeceira ou guarda-sol ou torradeira é aprovado. A empresa contrata consumidores para testar várias marcas e modelos concorrentes e fazer suas 
recomendações. Essas pessoas 'beijam alguns sapos' para que você não precise fazê-lo.

O cliente precisa ter confiança nos serviços que estão sendo oferecidos, pois as organizações que satisfazem as necessidades de seus clientes ampliam suas possibilidades de sucesso. Porém, precisa, antes de tudo, não deduzir, mas identificar verdadeiramente quais são as reais necessidades de seus clientes e atendê-las. Preferivelmente, deve até mesmo superá-las, de forma a manter o cliente no longo prazo.

\section{7 - O MARKETING DO SERVIÇO AOS CLIENTES}

Walker (1991), "diz que no modelo da estratégia de serviços, os clientes estão constantemente medindo o serviço real ou o serviço percebido de acordo com a imagem que você esta projetando e as promessas que esta fazendo. Eles também falam sobre suas experiências com outros clientes potenciais e criam suas expectativas e preconceitos. Se o serviço aos clientes realmente é diferente dos concorrentes, você precisa falar sobre isso com os clientes. Mas, se você não conseguir corresponder à sua própria propaganda, não será bem tratado no mercado".

Se você não conseguir satisfazer às expectativas que criou deliberadamente no cliente, terá sido o autor de seu próprio fracasso. A publicidade eleva as expectativas do cliente a um certo nível. Se o produto ou serviço corresponder a essas expectativas, a posição no mercado é fortalecida, mas, ao mesmo tempo, os clientes esperarão um serviço ainda melhor na próxima vez em que o procurarem.

O marketing de serviço está voltado, basicamente para o tratamento adequado do consumidor, na interpretação e leitura adequada de suas necessidades, levando-se em conta os fatores que influenciam em seu comportamento.

\subsection{1 - O SIGNIFICADO DA PERCEPÇÃO, REAÇÃO E A CONFIABILIDADE DO CLIENTE.}


Ao se elaborar um questionário ou uma escala para avaliar as reações e percepções do cliente em relação às suas necessidades, é necessário levar em conta certas questões para assegurar que o resultado fornecido por este instrumento reflita informações precisas acerca destes conceitos básicos.

A importância da precisão de medição quando da avaliação da satisfação do cliente é semelhante à importância da precisão de instrumentos para a medição de dimensões de objetos reais, tais como peças mecânicas.

Os índices de repetibilidade e confiabilidade do instrumento, por exemplo, são concebidos para determinar a qualidade do processo de medição de dimensões em ambientes de produção industrial. Da mesma forma, os índices estatísticos podem refletir a qualidade da medição dos questionários de satisfação. Existem duas características importantes de medição a serem consideradas quando do desenvolvimento de questionários, que são a confiabilidade e a validação. Hayes, (2001).

Quando desenvolvemos um questionário que avalia a percepção dos clientes acerca da qualidade do serviço ou produto, queremos ter certeza de que as medições estão isentas de erros aleatórios. Isto é, queremos ter certeza de que o nível básico de percepção da qualidade ou da satisfação está refletido com precisão nos resultados do questionário. Quando erros aleatórios são introduzidos nas medições, o resultado observado é menos confiável. Quando erros aleatórios são introduzidos nas medições, o resultado observado é menos confiável para estimar o valor básico verdadeiro. Os erros de medição são examinados dentro do contexto da confiabilidade. Hayes, (2001).

\subsection{2 - TEORIA CLÁSSICA DA MEDIÇÃO}

Quando avaliamos um nível de satisfação do cliente, o melhor que podemos fazer é pedir que a pessoa responda algumas perguntas. A partir das respostas, obtemos um resultado que indica o nível de satisfação da pessoa com o produto ou serviço. Contudo, isso apenas nos deixa com um resultado do nível de satisfação daquela pessoa.

De acordo com a teoria clássica da medição esse resultado observado é composto de um resultado verdadeiro (que é o nível real de satisfação), e um 
componente de erro de medição. Este erro é assumido como sendo aleatório e não está relacionado ao valor verdadeiro.

A equação básica da teoria clássica da medição, conhecida como modelo clássico de medição, descrevem a relação entre os valores observados, os verdadeiros e o erro. Hayes, (2001).

$$
X=T+E
$$

A satisfação do consumidor é, para as empresas, o único meio de conseguir obter e manter clientes. Ela constitui, portanto, um objetivo imprescindível para as organizações.

A satisfação é um estado psicológico, isto é, individual. O consumidor é visto como ser isolado e não como alguém que se insere em uma coletividade, que influência não só os seus desejos e expectativas, como também a natureza e o significado das relações existentes entre vendedores e compradores. Chauvel, (2000. P 11).

\subsection{3 - FERRAMENTAS PARA DESENHO DE PRODUTOS E SERVIÇOS}

Duas das mais novas e mais inovadoras técnicas para identificar como agradar o cliente e como combater a concorrência, são o desdobramento da função qualidade (QFD ${ }^{1}$ - Quality Function Development) e o método de Taguchi.

Como o cliente é o centro da estratégia de organização horizontal, qualquer técnica que enfoque o cliente é importante.

O QFD ${ }^{1}$ é um grande avanço na avaliação dos clientes, e pode ser uma ferramenta importante para ajudar a focalizar o cliente. O QFD quando é feito corretamente, o planejamento de produtos pode resultar em melhorias drásticas de produtividade, qualidade e satisfação do cliente. Denton, (1995) P 59.

A função da produção na organização, representa a reunião de recursos destinados à produção de seus bens e serviços" (NIGEL et al, 1996, p. 28). Em uma empresa de pesquisa de mercado, o seu mix de serviços/produtos é composto pelos projetos de pesquisa. A relação "input-transformação-output" (NIGEL et al, 1996) de uma empresa deste ramo é retrato da influência da engenharia de produção. 
Quanto mais próxima do mercado à empresa se coloca, quanto mais sintonizada com os valores de troca de um mercado específico e quanto maior a compreensão das variáveis que regem um determinado mercado, maior pode ser a segurança da empresa em suas tomadas de decisão ou proposições de planos estratégicos.

1 QFD - (Quality Function Development)

\section{METODOLOGIA}

\section{1 - TIPO DE PESQUISA}

Para este projeto foi utilizada a pesquisa bibliográfica, cobrindo as principais bases de dados, com documentos que subsidiassem a abordagem pretendida na pesquisa.

As premissas descritas na presente pesquisa (problema, objetivos e a indicação preliminar dos fundamentos teóricos) apontam para a abordagem 
metodológica quantitativa. Assim, de acordo com a indicação dos objetivos e do delineamento teórico preliminar, estão descritas no quadro a seguir as técnicas e as fontes de coleta e o tipo de análise apropriada a cada um dos objetivos.

\begin{tabular}{|c|c|c|c|}
\hline FASES & TÉCNICA & ANÁLISE & FONTE \\
\hline (1) & $\begin{array}{l}\text { Aplicação do } \\
\text { Questionário }\end{array}$ & $\begin{array}{l}\text { Análise do } \\
\text { conteúdo / } \\
\text { Estatística }\end{array}$ & Clientes \\
\hline (2) & $\begin{array}{c}\text { Pesquisa } \\
\text { bibliográfica }\end{array}$ & $\begin{array}{c}\text { Análise do } \\
\text { conteúdo / Análise } \\
\text { da literatura }\end{array}$ & $\begin{array}{c}\text { Dados estatísticos } \\
\text { coletados } \\
\text { /Literatura }\end{array}$ \\
\hline
\end{tabular}

O estudo consistiu em dois estágios: o primeiro estágio foi à análise das informações existentes no banco de dados que permitiu traçar o perfil da empresa; o segundo estágio foi o estudo de mercado com a utilização de questionário aplicado aos clientes que reuniu o conjunto de informações necessárias para aplicação das ferramentas de marketing e permitiu analisar as proposições sobre o tema de satisfação dos clientes.

Foram utilizados para esta pesquisa dados selecionados segundo sua importância e capacidade de geração de informações importantes para este estudo, Utilizando-se questionários com perguntas e respostas fechadas, o que não deu direito aos clientes falar suas próprias opiniões.

A empresa gira sob a denominação social de Valdecir Nunes dos Santos inscrita no CNPJ No 08.228.507/0001-09, com o nome fantasias de Mercado Triunfo, constituída em 08 de agosto de 2008, em Vicente Pires cidade satélite de BrasíliaDF, a empresa é composta de um sócio proprietário o Sr.Valdecir Nunes dos Santos, na qual a responsabilidade é integralmente sua, onde sua estrutura organizacional foi desenhada de forma centralizada, ou seja, o poder é centralizado 
nas mãos do dono da empresa, cabendo a ele decidir o que fazer ou não fazer, possuindo a maior autoridade dentro da empresa.

A empresa conta hoje com um atual quadro de 05 (cinco) funcionários, ambos os sexos, e estado civil, todos com atividades delegadas, definidas por departamento, incluindo caixas, repositores, empacotadores, limpeza e ainda com o apoio de 01 (um) contador externo, todos os funcionários são treinados, para que o atendimento seja um diferencial no mercado consumidor.

Os estudos sobre satisfação do cliente e suas formas de pesquisa continuam evoluindo, criando novos parâmetros e consolidando alguns conceitos.

Percebeu-se, então, um grande desenvolvimento histórico e qualitativo dos modelos e técnicas de pesquisas utilizados no âmbito da satisfação do cliente.

\subsubsection{PLANO DE AMOSTRAGEM}

No universo dos clientes que foram pesquisados obteve-se informações através do banco de dados do mercado, bem como de novos clientes que possam surgir no período da pesquisa, utilizando as técnicas censitárias, em que todos os elementos do universo foram pesquisados. Isso se justifica pela importância de representatividade qualitativa dos elementos deste universo.

Mattar (1999, p. 63), "expõe a questão das pesquisas por censo da seguinte forma:" quando se pretende conhecer aspectos de uma população, há dois caminhos a seguir: ou se pesquisam todos os seus elementos, e neste caso o estudo é chamado censo, ou apenas uma amostra deles, onde é chamado de pesquisa “. Para Mattar (1999), o censo deve ser utilizado como abordagem amostral quando a população for pequena; quando os dados a respeito da população forem facilmente obteníveis; quando os requisitos do problema da pesquisa impõem a obtenção de dados específicos de cada elemento da população; e quando for uma imposição Legal".

Na amostragem censitária, o projeto fica submetido à ocorrência de um erro conhecido como erro não amostral. "Os erros não amostrais são os cometidos durante o processo de pesquisa de marketing que não sejam oriundos do tamanho e do processo de seleção da amostra".(Mattar, 1999, p. 60). Este desvio na amostra ocorre devido à dificuldade que pode ser encontrada pelos pesquisadores ao coletar os dados no mercado. 
O censo se propõe a pesquisar todos os elementos do universo, porém, podem acontecer vários desvios: um determinado elemento está inacessível, um outro se recusou a responder e até mesmo um que começou a responder, mas desistiu no meio da entrevista, exigindo o cancelamento do roteiro de entrevistas.

Estes erros podem acontecer e o pesquisador não tem com controlá-los. "Inúmeras são as fontes de erros não amostrais em pesquisas de marketing, e ao pesquisador cabe apenas tomar o máximo cuidado, durante as várias etapas do processo, para minimizar a sua ocorrência". (Mattar, 1999, p. 62).

Este projeto se organizou no esforço de pesquisar todos os elementos da amostra, enriquecendo a análise dos dados com os vários "universos" vividos e expostos por cada componente. Foram aplicados 21 (vinte e um) questionários aos clientes do Mercado Triunfo, buscando identificar quais os pontos que necessitam de melhoria para alcançar a satisfação dos clientes: tais como facilidade de encontro dos produtos, instalações física, qualidade dos produtos e serviços oferecidos.

\subsection{2 - INSTRUMENTO DE PESQUISA}

Segundo Mattar (1999), instrumento de coleta de dados é o documento através do qual as perguntas são apresentadas aos respondentes e registradas suas respostas. Chama-se, genericamente, de instrumento de coleta de dados a todos os possíveis formulários utilizados para relacionar dados a serem coletados e/ou registrar os dados coletados, utilizando-se de qualquer forma de administração (questionários, formulários para anotações de observações, tópicos a serem seguidos durante uma entrevista etc.).

Para coletar os dados sobre o público-alvo do estudo e descrever os aspectos que envolvem tal público, foi executada uma pesquisa que teve como técnica de coleta de dados o uso de um questionário.

O questionário é uma ferramenta que ao ser utilizada demonstrou o nível de satisfação dos clientes do Mercado Triunfo, considerando diversos aspectos.

Foi utilizado o questionário já validado por (PRADO \& MARCHETTI, 1997), que comparava os parâmetros de excelência em cada fator (eficácia nos serviços de caixa, espaço físico, serviço de panificação, presteza no atendimento, qualidade das carnes), bem como comparava a excelência dos serviços dentro do mercado. 
O questionário foi estruturado com 10 (dez) perguntas fechadas, ou seja, perguntas objetivas com respostas objetivas. Utilizou-se a pergunta objetiva tendo em vista que se apresenta mais fácil para o público pesquisado responder, o que possibilitou a execução da pesquisa de campo com maior rapidez e segurança.

O Mercado Triunfo está no mercado aproximadamente há 02 (dois) anos, dessa forma já possui uma boa clientela, sendo que o questionário foi aplicado para 21 (vinte e um) pessoas, que constitui uma quantidade possível para identificar a satisfação do público entrevistado.

\subsection{3 - DESCRIÇÃO DO INSTRUMENTO}

Buscou-se o modelo do questionário validado por Prado \& Marchetti, (1997), utilizado na pesquisa de campo de um Supermercado, que continha 19 (dezenove) questões (conforme anexo I).

Utilizamos apenas 10 (dez) questões deste questionário, as questões escolhidas foram as que mais se aplicou ao tema da monografia, pois se trata de um mini mercado, com pouco espaço físico, uma pequena variedade de produtos. As 09 (nove) questões restantes não foram utilizadas, pois se tratava de questões voltadas para um Supermercado com filiais, onde a variedade de produtos é bem mais diversificada, o espaço físico do Supermercado é maior e o índice de clientes é bem mais complexo.

\subsection{4 - MÉTODO DE COLETA DE DADOS}

Os formulários foram preenchidos pessoalmente, sempre garantindo uniformidade no discurso do entrevistador e a menor interferência possível deste nas repostas, a fim de validar análise qualitativa subseqüente.

Nesta pesquisa de campo, a amostragem foi coletada em vários períodos (vários dias da semana durante os períodos matutinos, vespertinos e noturnos) buscando ser mais representativa possível, sendo um total de 21 (vinte e um) questionários, aplicados entre os meses Abril e Maio de 2008.

$\mathrm{Na}$ coleta de dados, atribuir-se-á um número para cada cliente, a fim de garantir o sigilo dos dados coletados. Os dados utilizados para a pesquisa foram 
coletados no próprio mercado, entre os variados dias da semana e horários diferentes.

\section{APRESENTAÇÃO DOS RESULTADOS E ANÁLISE DOS DADOS COLETADOS}

O interesse ao desenvolver este estudo surgiu da necessidade de medir o grau de satisfação dos clientes de uma empresa do ramo de produtos alimentícios, e entender a importância da satisfação do cliente para a sobrevivência da empresa no mercado, assim avaliar a satisfação dos mesmos para identificar se estes estão satisfeitos com nossos produtos, atendimentos e serviços, considerando-se a 
necessidade de tornar-se mais competitiva melhorando a qualidade dos serviços, com isso, aumentando o nível de satisfação.

A busca pela satisfação dos clientes e a oportunidade de desenvolver um estudo acadêmico na empresa, demonstrou o interesse do proprietário em compreender a importância de um diferencial nos produtos, atendimento, partindo do princípio de que somente permanecem no mercado as empresas que identificam as necessidades e desejos de seus clientes e oferecendo o que estes buscam, a preços acessíveis, bons produtos e qualidade no atendimento.

$1^{\text {a }}$ Questão: É fácil achar os produtos que preciso no mercado Triunfo?

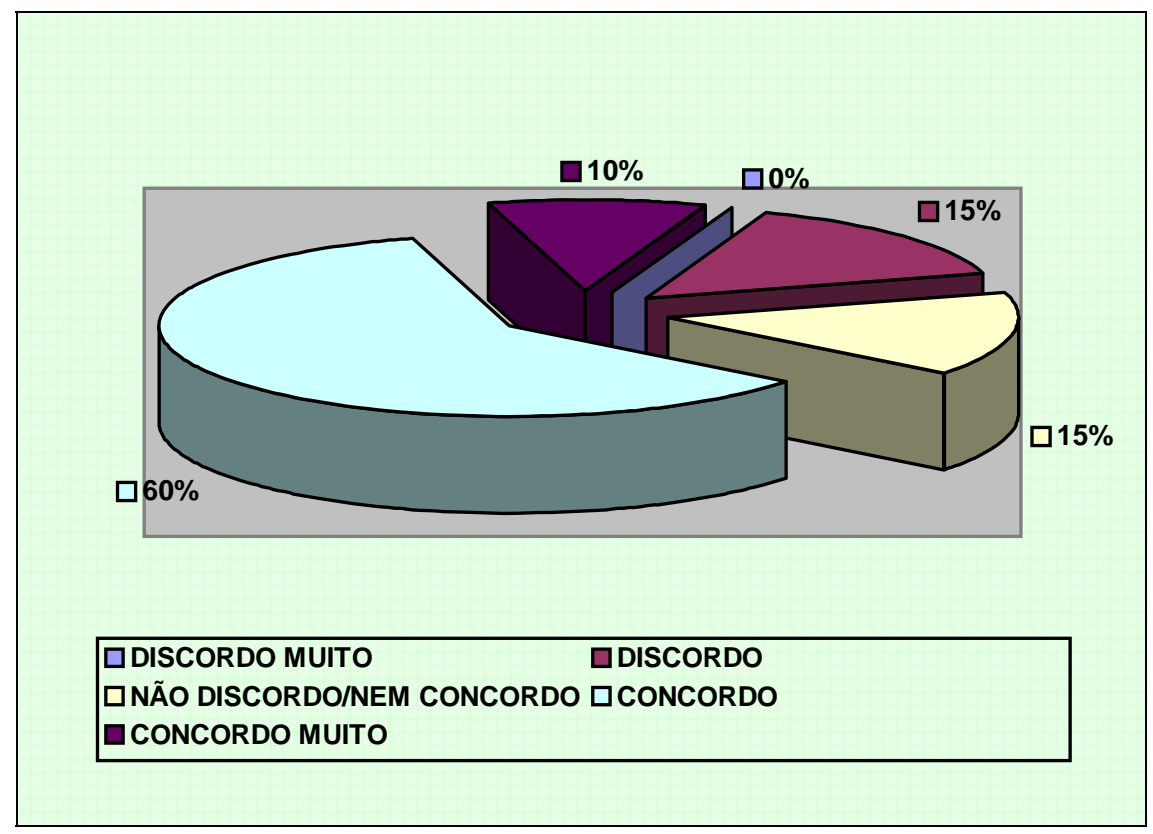

Gráfico 1: Localização dos produtos Fonte: Elaboração própria

Em relação à localização dos produtos no mercado, obteve-se:

$0 \%$ : Clientes que discorda muito

15\%: Clientes que discorda

15\% : Clientes que não discorda e nem concorda

60\%: Clientes que concorda

10\%: Clientes que concorda muito

Obteve-se um resultado de $60 \%$ dos clientes que concorda com a facilidade de achar os produtos. 
Assim, considerou-se que há indícios de que é fácil achar os produtos nas prateleiras do mercado.

Na seqüência da pesquisa, procurou-se saber sobre o espaço físico, os quais assim, responderam:

$2^{\text {a }}$ Questão: No mercado Triunfo o espaço entre os caixas e as prateleiras é amplo para receber os seus clientes?

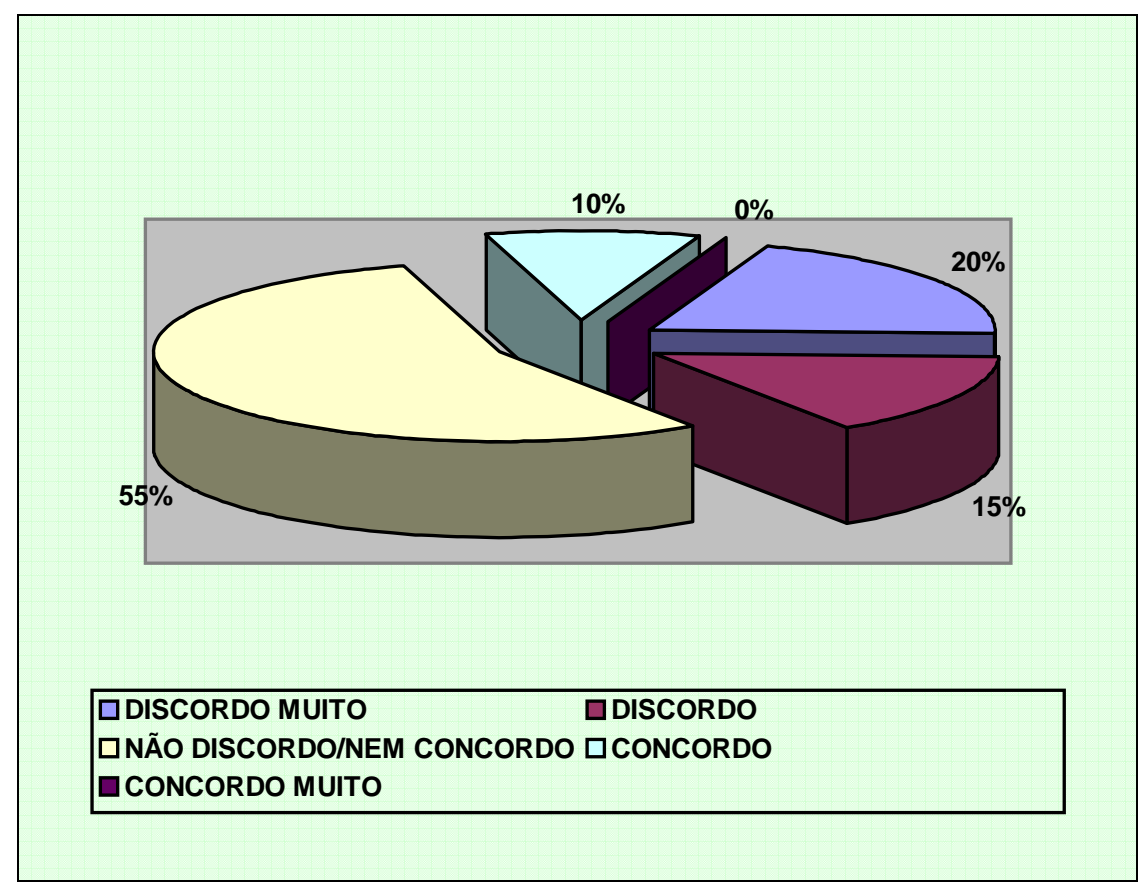

Gráfico 2: Espaço Físico

Fonte: Elaboração própria

Em relação ao espaço entre os caixas e as prateleiras para receber os clientes, obteve-se:

20\% : Clientes que discorda muito

15\%: Clientes que discorda

55\% : Clientes que não discorda e nem concorda

10\%: Clientes que concorda

$0 \%$ : Clientes que concorda muito

Obteve-se um resultado de $55 \%$ de clientes que não discorda e nem concorda com os espaço físico entre os caixas e as prateleiras do Mercado Triunfo. 
Assim, avaliou-se que a uma indecisão dos clientes do Mercado Triunfo que acha que o espaço físico entre os caixas e as prateleiras seja amplo para receber seus clientes.

Ainda na seqüência da pesquisa, procurou-se saber sobre a variedade de produtos, os quais assim, responderam:

$3^{\text {a }}$ Questão: O Mercado Triunfo oferece boa variedade de produtos?

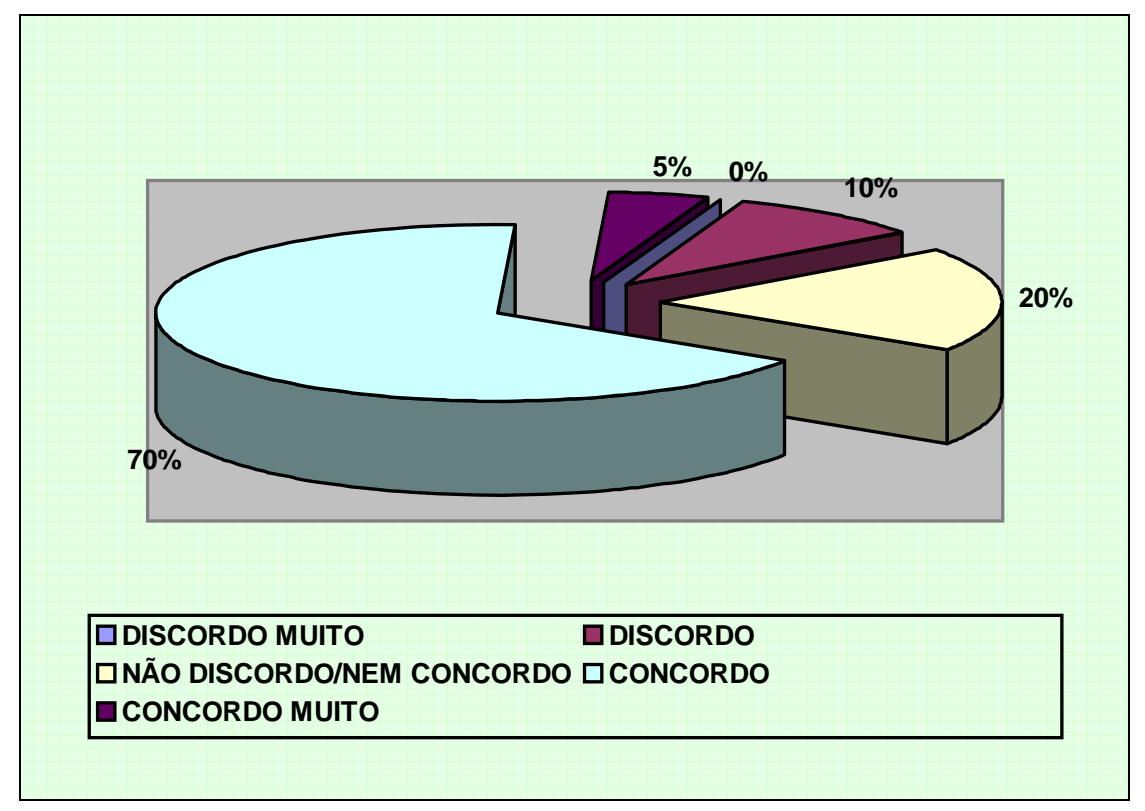

Gráfico 3: Variedade de produtos

Fonte: Elaboração própria

Em relação à variedade dos produtos do mercado, obteve-se:

0\%: Clientes que discorda muito

10\%: Clientes que discorda

20\%: Clientes que não discorda e nem concorda

70\%: Clientes que concorda

5\%: Clientes que concorda muito

Obteve-se um resultado de $70 \%$ de clientes que concorda com a variedade de produtos.

Assim, considerou-se, que os clientes do Mercado Triunfo estão satisfeito com a variedade de produtos encontrados no mercado. 
Na seqüência da pesquisa, procurou-se saber sobre a iluminação dos produtos, os quais assim, responderam:

$4^{\text {a }}$ Questão: Os produtos do Mercado Triunfo estão bem iluminados?

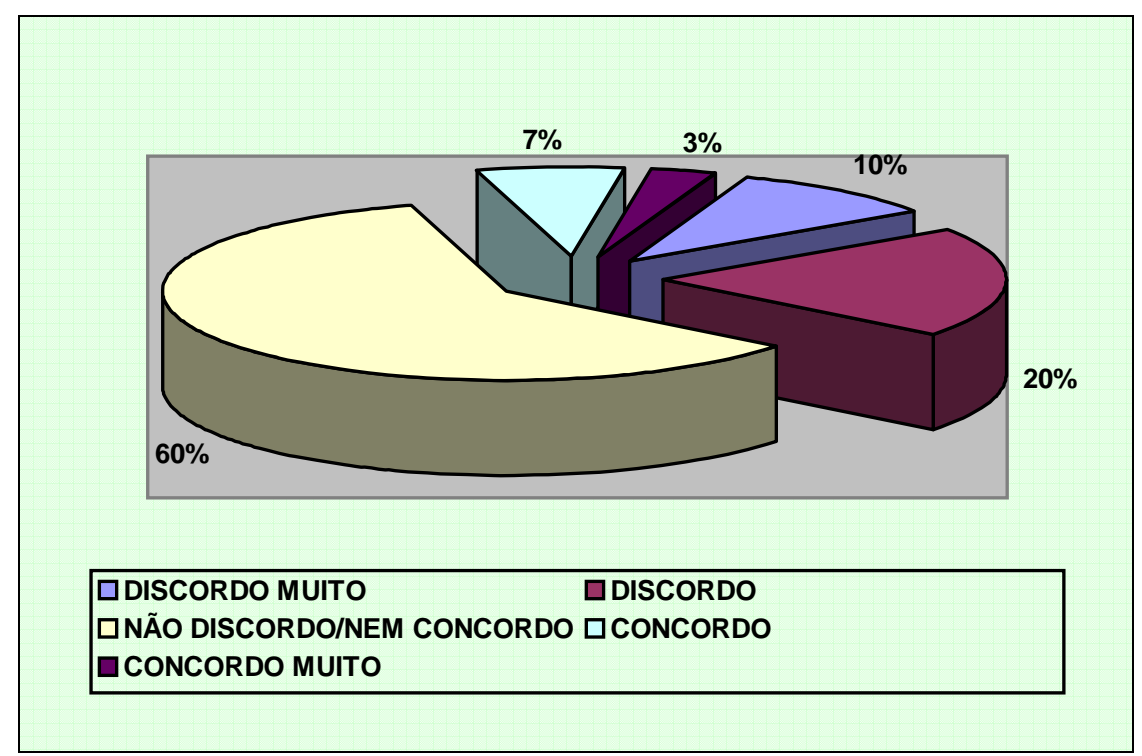

Gráfico 4: lluminação dos produtos

Fonte: Elaboração própria

Em relação à iluminação dos produtos no mercado, obteve-se:

10\%: Clientes que discorda muito

20\%: Clientes que discorda

60\% : Clientes que não discorda e nem concorda

7\%: Clientes que concorda

3\%: Clientes que concorda muito

Obteve-se um resultado de 60\% para clientes que nem discorda e nem concordam com a iluminação dos produtos.

Assim, considerou-se, que mais da metade dos clientes do Mercado Triunfo estão indecisos com a iluminação dos produtos nas prateleiras.

Ainda na seqüência da pesquisa, procurou-se saber sobre a qualidade das carnes, os quais assim, responderam: 
$5^{\text {a }}$ Questão: As carnes no mercado Triunfo estão sempre frescas, com boa aparência, e possuem boa qualidade?

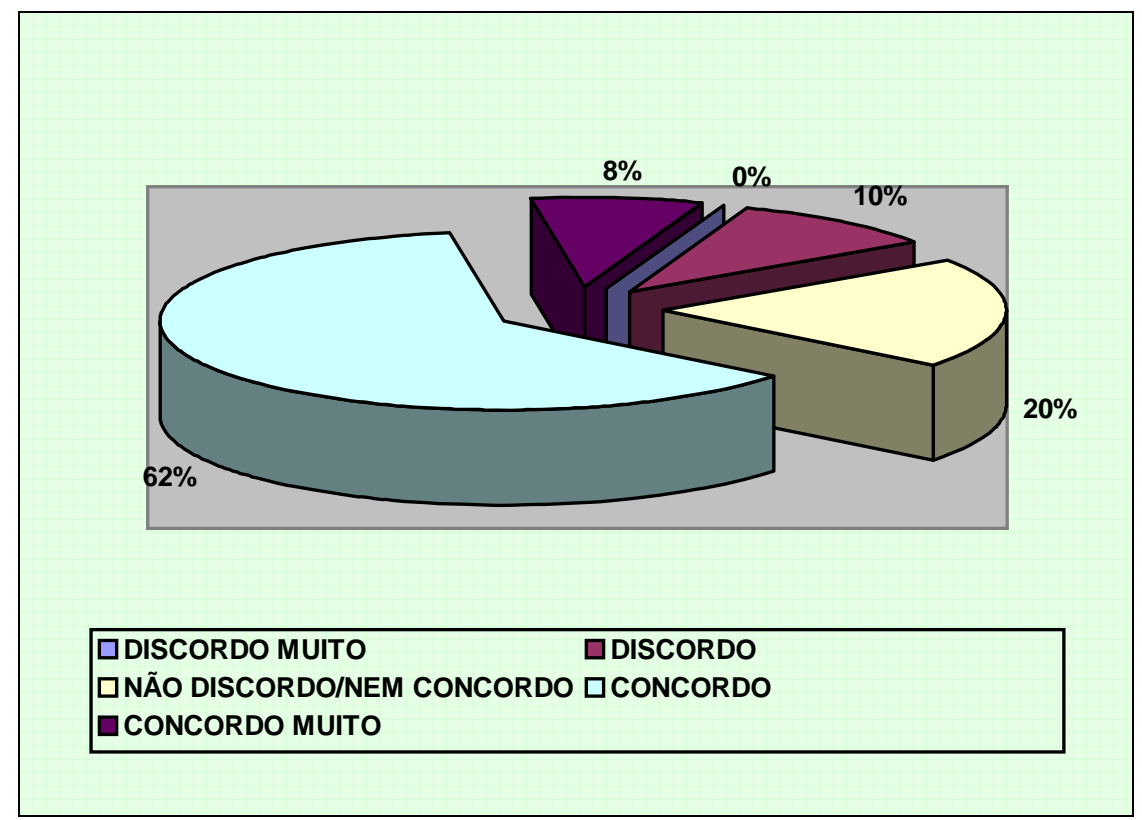

Gráfico 5: Aparência e qualidade das carnes

Fonte: Elaboração própria

Em relação à aparência e qualidade das carnes, obteve-se:

$0 \%$ : Clientes que discorda muito

10\%: Clientes que discorda

20\%: Clientes que não discorda e nem concorda

62\%: Clientes que concorda

8\%: Clientes que concorda muito

Obteve-se um resultado de $62 \%$ para clientes que concordam com a aparência e a qualidade das carnes do mercado.

Considerou-se assim, que os clientes do Mercado Triunfo estão satisfeitos com a aparência e a qualidade das carnes do mercado.

Na seqüência da pesquisa, procurou-se saber sobre a validade dos alimentos nãoperecíveis, os quais assim, responderam:

$6^{\text {a }}$ Questão: Os produtos da seção de alimentos não-perecíveis do mercado Triunfo estão sempre com a validade correta? 


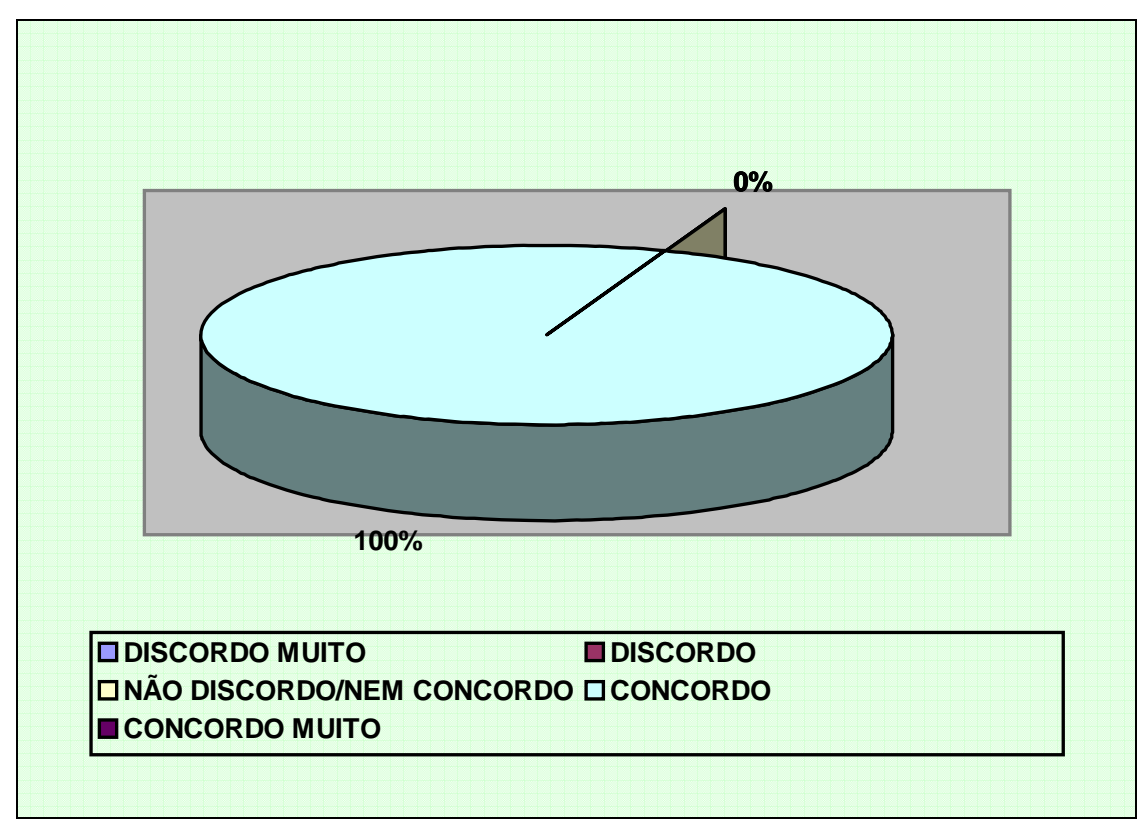

Gráfico 6: Validade dos produtos não-perecível Fonte: Elaboração própria

Em relação à validade dos produtos não perecíveis encontrados no mercado, obteve-se:

0\% : Clientes que discorda muito

$0 \%$ : Clientes que discorda

0\% : Clientes que não discorda e nem concorda

100\%: Clientes que concorda

$0 \%$ : Clientes que concorda muito

Obteve-se um resultado de $100 \%$ para clientes que concordam com a validade dos produtos não-perecíveis encontrados no mercado.

Assim, considerou-se, que os clientes do Mercado Triunfo estão muito satisfeitos com a correta validade dos produtos não-perecíveis do mercado. Ainda na seqüência da pesquisa, procurou-se saber sobre variedade de produtos da padaria, os quais assim, responderam:

$7^{a}$ Questão: 0 mercado Triunfo oferece uma variedade de produtos na sua padaria? 


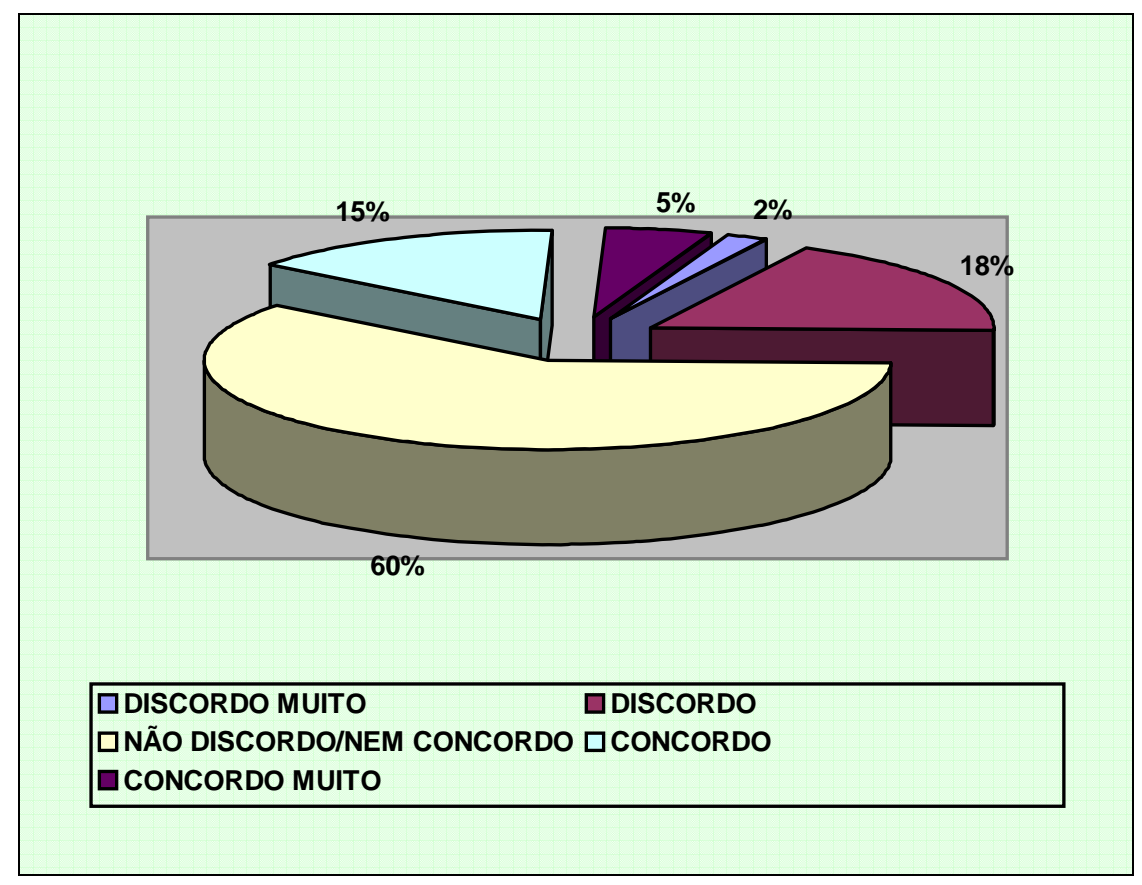

Gráfico 7: Variedade de produtos na padaria Fonte: Elaboração própria

Em relação à variedade dos produtos na padaria, obteve-se:

$2 \%$ : Clientes que discorda muito

18\%: Clientes que discorda

60\% : Clientes que não discorda e nem concorda

15\% : Clientes que concorda

5\%: Clientes que concorda muito

Obteve-se um resultado de $60 \%$ para clientes que nem discordam e nem concordam com a variedade dos produtos na padaria.

Considerou-se, assim, que mais da metade dos clientes do Mercado Triunfo, estão indecisos com a variedade de produtos na padaria.

Continuando na seqüência da pesquisa, procurou-se saber sobre exposição dos produtos da padaria, os quais assim, responderam:

$8^{a}$ Questão: Os produtos na padaria do mercado Triunfo são bem expostos? 


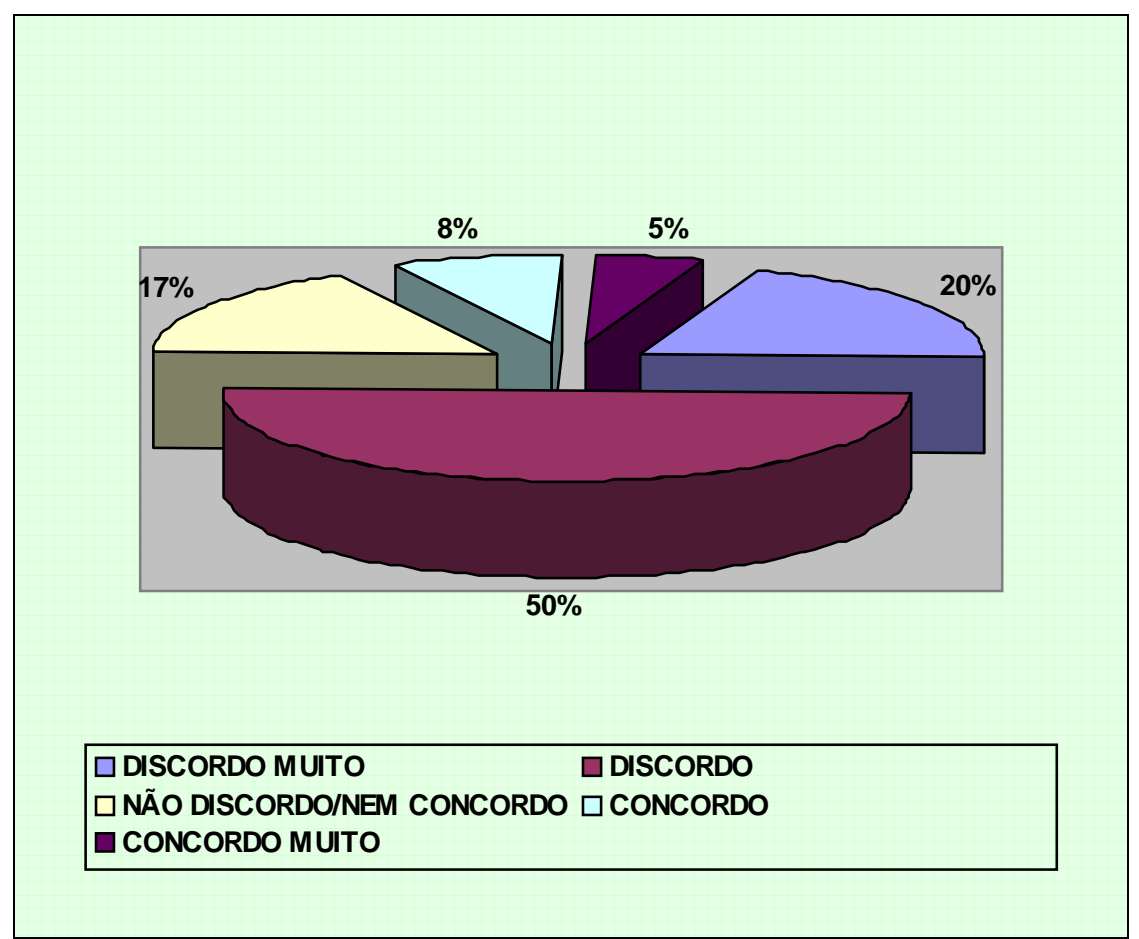

Gráfico 8: Exposição dos produtos da padaria Fonte: Elaboração própria

Em relação à exposição dos produtos da padaria, obteve-se:

\section{0\%: Clientes que discorda muito}

50\% : Clientes que discorda

$17 \%$ : Clientes que não discorda e nem concorda

8\% : Clientes que concorda

\section{$5 \%$ : Clientes que concorda muito}

Obteve-se um resultado de 50\% para clientes que discordam com exposição dos produtos da padaria.

Assim, considerou-se, que a metade dos clientes do Mercado Triunfo discordam com exposição dos produtos da padaria, ou seja, não estão satisfeitos com a exposição dos produtos da padaria do mercado.

Ainda na seqüência da pesquisa, procurou-se saber sobre o frescor e o sabor dos Paes e doces, os quais assim, responderam:

$9^{a}$ Questão: Os pães e doces do mercado Triunfo estão sempre frescos e com sabor agradável? 


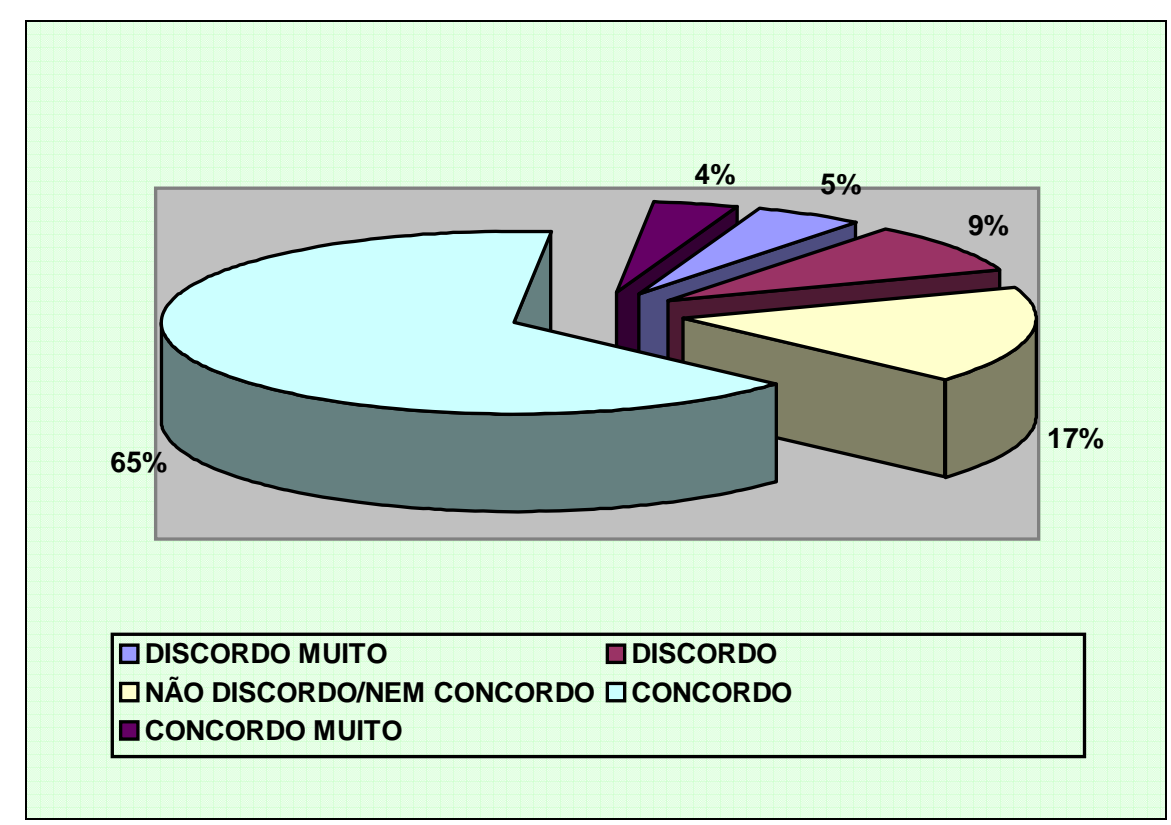

Gráfico 9: Sabor agradável dos pães

Fonte: Elaboração própria

Em relação ao sabor dos pães e doces do mercado, obteve-se:

5\%: Clientes que discorda muito

9\%: Clientes que discorda

17\% : Clientes que não discorda e nem concorda

65\% : Clientes que concorda

4\%: Clientes que concorda muito

Obteve-se um resultado de $65 \%$ para clientes que concordam com o frescor e o sabor dos pães e doces da padaria.

Assim, considerou-se, que mais metade dos clientes do Mercado Triunfo estão satisfeito com o frescor e o sabor dos pães e doces da padaria.

Para finalizar a pesquisa, procurou-se saber sobre os erros dos equipamentos utilizados nos caixas, os quais assim, responderam:

$10^{a}$ Questão: No mercado Triunfo os equipamentos utilizados nos caixas possibilitam menos erros na operação? 


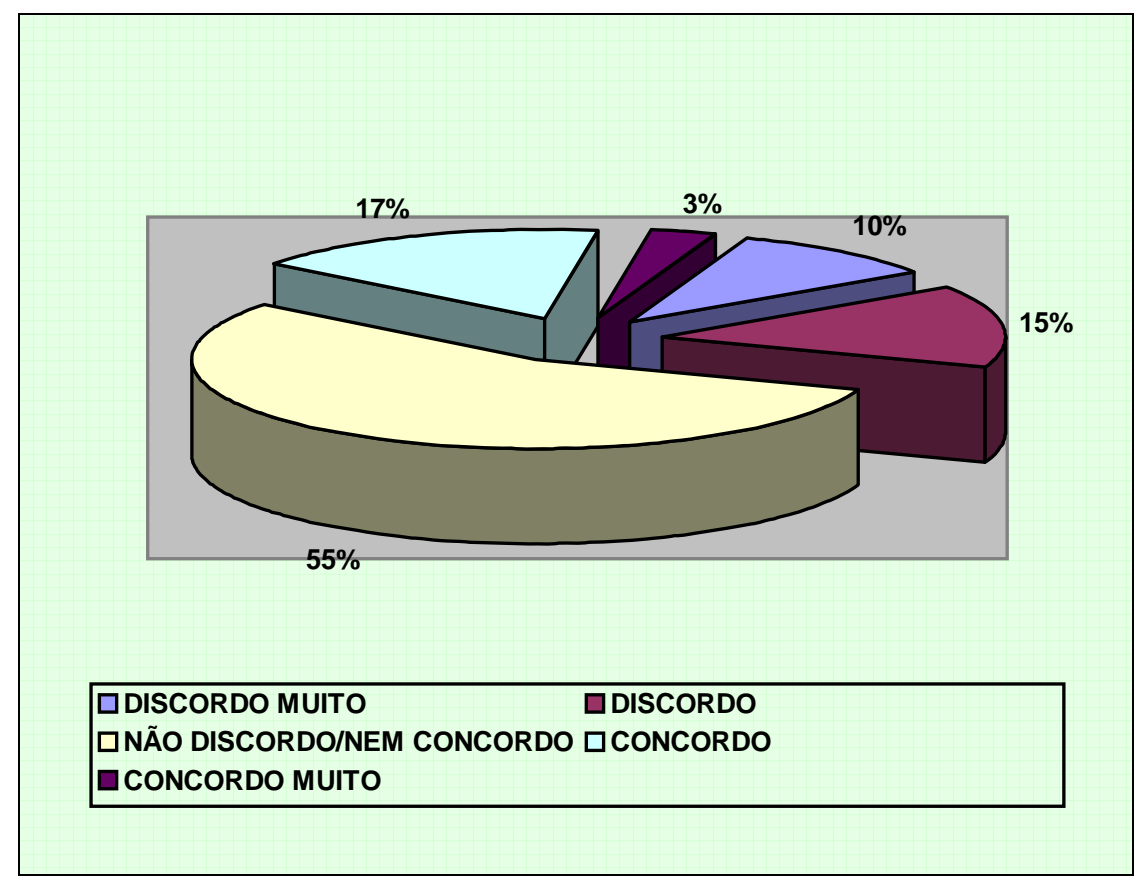

Gráfico 10: Erros nas operações nos caixas

Fonte: Elaboração própria

Em relação aos equipamentos utilizados nos caixas possibilitam menos erros nas operações, obteve-se:

10\%: Clientes que discorda muito

15\%: Clientes que discorda

55\%: Clientes que não discorda e nem concorda

17\%: Clientes que concorda

$3 \%$ : Clientes que concorda muito

Obteve-se um resultado de 55\% para clientes que não discordo e nem concorda com os equipamentos utilizados nos caixas que possibilitam menos erro erros nas operações.

Considerou-se, assim, que mais da metade dos clientes estão indecisos com os equipamentos utilizados nos caixas que possibilitam menos erro nas operações, ou seja, não quiseram dar opinião com relação aos erros dos equipamentos nos caixas. 
Entretanto, um dado interessante percebido na pesquisa de acordo com as respostas acima foi que mais da metade dos clientes demonstram uma satisfação com os produtos e serviços prestados, uma vez que a maioria respondeu que concordam com a facilidade de localização dos produtos, espaço físico para as instalações e serviços, oferecidos no Mercado Triunfo, correspondendo a 60\% das respostas.

Dentre esse dado analisou-se que os clientes que possuem renda mensal média vêem a pesquisa de um modo diferente, ou seja, com outros olhos, do restante que possuem uma renda média baixa, demonstrando assim que a renda influencia sim na opinião desses, pois os clientes que possuem uma renda melhor, propicia uma boa qualidade de vida para seus familiares, também foi percebido que $40 \%$ dos clientes não discordam e nem concordam, ou seja, esses não quiseram optar nas pesquisas, são os clientes indecisos.

Um fato interessante percebido nas respostas enfatiza que entre os clientes mais velhos, com idade média de 40 anos, composta por uma maioria do sexo feminino, que acham importante essa pesquisa de satisfação, sendo indiferente para os mais novos, devido ao fato de que os clientes mais velhos tenham mais tempo fazer pesquisa de preços, de prazos, e de produtos, e os clientes mais novos não tenham tanto tempo para pesquisar e compram no primeiro estabelecimento que vêem pela frente.

De acordo com Berry \& Parasuraman (1992), "consideram que os clientes utilizam os aspectos tangíveis associados aos serviços, como indicadores de sua qualidade, e estes estariam ligados a três categorias: o ambiente físico, as comunicações e o preço".

$\mathrm{O}$ ambiente físico compreende em fatores ambientais (qualidade do ar, ruídos, odores, limpeza), em fatores de projeto (funcionais como conforto, sinalização) e em fatores sociais (clientes e funcionários em termos de número, aparência e comportamento).

As comunicações, que podem ser, positivas e negativas, são oriundas da própria empresa, de grupos interessados e da mídia em geral. O papel das comunicações é tornar o serviço, em mensagem mais tangível, dando ênfase aos aspectos tangíveis do serviço nas comunicações, criando a representação tangível do serviço para dar o apoio à comunicação do significado e benefícios, estimulando 
o marketing boca-a-boca favorável, para garantir os serviços prestados (MIRANDA, 2001).

Quanto ao preço, os clientes o utilizam como indício do produto, pois, dada a intangibilidade do serviço, o preço se torna um indicador visível do nível e da qualidade do serviço. Quando os preços estão baixos demais, a percepção do cliente é no sentido de desvalorização do mesmo, pois questiona que a especialização e capacitação o sustentam. Quando os preços estão altos demais, as expectativas do cliente se elevam, esperando um serviço de altíssimo nível; porém podem também transmitir uma mensagem de despreocupação com o cliente ou de estar sendo lesado.

A forma como a empresa administra seus serviços proporciona aos clientes e funcionários a imagem mental da sua estratégia de marketing, indicando como a empresa deseja que eles se sintam e reajam. Os funcionários representam para os clientes o próprio serviço, portanto devem entender e adquirir controle sobre os serviços que realizam. Desta forma o uso adequado dos serviços possibilitou aos clientes e funcionários uma idéia clara do serviço e seu posicionamento.

A pesquisa de campo consistiu em entrevistar os clientes do Mercado Triunfo, através de um questionário estruturado, apresentado na tabela 1, com 0 objetivo de avaliar os aspectos como localização, instalações, serviços e produtos.

Para discutir o modelo de questões de estratificação sócio-econômico utilizado na pesquisa, adotou-se o modelo feito por Prado \& Marchetti (1997), que analisam a satisfação com relação à experiência de compra e ao pacote de serviços oferecido ao cliente. Na pesquisa foram identificadas as dimensões ao conceito de satisfação, que seriam: eficácia nos serviços de caixa (equipamentos e comunicação), aspectos de conveniência (variedade, validade dos produtos), serviços de panificação, carnes (variedade e qualidade, aparência e exposição).

Os resultados apresentados mostram que, ao atuar de maneira eficaz nos atributos considerado relevantes para os clientes, proporcionou-se uma satisfação para os mesmos, uma vez que se atendeu às suas expectativas. 


\section{CONCLUSÃO}

Através desta pesquisa foi concluído que apesar de haver uma apreciação por parte dos clientes em relação aos serviços do mercado, os mesmos acharam importante, a aplicação do questionário de pesquisa de satisfação, que acompanhou o desenvolvimento das atividades por parte dos funcionários no atendimento e em outros serviços.

Quanto às finalidades, valores e resultados durante a pesquisa, os clientes se mostraram altamente favoráveis, marcando a maioria das opções relacionadas à cooperação e maior apreciação pelos serviços.

Considerando-se que a satisfação dos clientes é essencial para o bom andamento das atividades nas empresas, e sempre deve-se estar preocupado com este assunto, pois como já foi dito o cliente sempre tem razão e com isso ele é a razão da existência da empresa, procurou-se analisar nos questionários que aplicamos na empresa, como estão nossos serviços, produtos, instalações e localização de nosso Mercado Triunfo.

Neste, contexto, buscou-se avaliar a excelência de serviços, observando a satisfação dos clientes. Assim, nesta monografia, apresentou-se a utilização de um instrumento de medida (PRADO \& MARCHETTI, 1997), já validado, para esse fim.

O principal objetivo foi discutir as dimensões da excelência de serviços do mercado, examinando as suas operações e o mix por ele oferecido a seus clientes.

A satisfação de clientes é um sistema de administração de informações que continuamente capta a voz do cliente, através da avaliação da performance da empresa a partir do ponto de vista do cliente. Esta pesquisa, assim, mede a qualidade externa ou desempenho da empresa em seus negócios, indicando caminhos para as decisões futuras de comercialização e marketing.

Há também, vários outros benefícios proporcionados pela pesquisa de satisfação de clientes: percepção mais positiva dos clientes quanto à empresa; informações precisas e atualizadas quanto às necessidades dos clientes; relações de lealdade com os clientes, baseadas em ações corretivas; e confiança desenvolvida em função de maior aproximação com o cliente. 
Segundo Gianesi (1996), "o tipo de relacionamento entre o cliente e a empresa, seja proveniente de uma ligação formal, seja resultante do processo de prestação do serviço, afeta a competitividade do fornecedor de serviços e deve ser considerado na formulação da estratégia de operações".

Assim, a partir dos dados que foram apresentados neste projeto, sugere-se que seja elaborado um novo questionário, para que elevem o senso de percepção da importância da pesquisa de satisfação de cliente, por meio de campanhas internas que melhorem a interação e entendimento entre os clientes e funcionários, já partindo do princípio que uma pesquisa de satisfação do cliente traz para a empresa uma imagem positiva. 


\section{REFERÊNCIAS BIBIOGRÁFICA}

BARABBA, V. P., 1934- A voz do mercado: A vantagem competitiva através da utilização criativa das informações do mercado / BARABBA V. P. e ZALTMAN; tradução bárbara Theoto Lambert; revisão técnica Kuciano Sabóia Lopes Filho. São Paulo: Makron, McGraw-Hill, 1992.

BERRY, L.L.; PARASURAMAN, A Serviços de marketing: competindo através da qualidade. Tradução: Beatriz Sidou. São Paulo: Maltese-Norma, 1992. 238p.

BOYD, H. W. \& WESTFALL, R. Pesquisa mercadológica: textos e casos. Rio de Janeiro: FGV, 1982, $5^{\circ}$ edição.

BROYDRICK, S. C. Valorizando o consumidor: como conquistar clientes e influenciar mercados / tradução Mauro Pinheiro. - São Paulo: Futura, 1997.

CHAUVEL, M. A. Consumidores insatisfeitos: uma oportunidade para as empresas / Marie Agnes Chauvel. - Rio de Janeiro: Maud, 2000.

CHIAVENATO. I. Gerenciando Pessoas: O passo decisivo para a Administração Participativa. São Paulo, Atlas 2000.

DEMO, P. Introdução à Metodologia da Ciência. São Paulo: Editora Atlas, 1988.

DENTO, D. K., Qualidade em serviços: o atendimento ao cliente como fator de vantagem competitiva. Tradução de Flavio Deny Steffen; revisão técnica de Jose Carlos de Castro Waeny. São Paulo: Makro: McGraw-Hill, 1990. 222 p. Titulo Original Quality Service.

DRUCKER, P. Administrando para o Futuro. São Paulo: Publifolha, 2000.

ELTZ, Fabio. Qualidade na comunicação: preparando a empresa para encantar o cliente. São Paulo: Casa da Qualidade, 1994.

FRANCESE, P. \& PIRTO, R. Capturando Clientes: Como atingir em cheio os clientes que consomem seus produtos. São Paulo. Makron Books. 1993.

GADE, C. Psicologia do consumidor - São Paulo: EPU, 1980.

GIANESI, I. G.N. Administração estratégica de serviços: operações para a satisfação do cliente - São Paulo: atlas, 1996. 
GODOY, A. S. A Pesquisa qualitativa e sua utilização em Administração de Empresas. Revista de Administração de Empresas, São Paulo, v. 35, n. 4, p. 65-71, jul. /ago. 1995.

GODRI, D. Conquistar e manter clientes. 32. ed. Blumenau-SC: Eko, 1994.

HAYES, B. E. Medindo a satisfação do cliente - tradução: Luiz Liske - Rio de Janeiro: Qualitymark Ed., 2001.

KOTLER, P. Administração de Marketing: a edição do novo milênio; tradução Bazán Tecnologia e Lingüística e Logística; revisão técnica Arão Sapiro. São Paulo: Prentice Hall, 2000.

KOTLER, P. Administração de Marketing: Análise, Planejamento, Implementação e Controle. 5. ed. São Paulo: Atlas, 1998.

MARTINS, M. \& CARDOZO, R. Marketing MBA Empresarial. 1 ed. Belo Horizonte: Fundação Dom Cabral, 2000.

MATTAR, F. N. Pesquisa de Marketing. 5. ed. - São Paulo: Editora Atlas, v.1, 1999.

MELO, Antônio Aguinaldo Arruda, Avaliação do nível de satisfação do cliente de telefonia fixa no novo modelo brasileiro de telecomunicações. UFPE. 2003.

(Dissertação de Mestrado).

MIRANDA, C.L. Satisfação do cliente em supermercado: a avaliação da qualidade dos serviços. 2001. 182f.. Dissertação (Mestrado em Engenharia de Produção)- Programa de Pós-graduação em Engenharia de Produção, UFSC, Florianópolis, SC.

NIGEL, Slack et al. Administração da Produção. São Paulo: Editora Atlas, 1996.

SEMENIK, Richard J. e BAMOSSY. Gary J. Princípios de Marketing: Uma perspectiva global. São Paulo: Makron Books,1995.

PRADO, P. H.M. MARCHETTI, R. Z. Excelência em supermercado: a dimensão da satisfação do consumidor. Revista de Administração, São Paulo, v. 32, n, 2 , p.58, 1997.

WALKER, D. $O$ cliente em primeiro Lugar: $O$ atendimento e a satisfação do cliente como uma arma poderosa de fidelidade e vendas / tradução Cecília Camargo Bartalotti; revisão técnica José Augusto do Nascimento. - São Paulo; Makron, 1991. 


\section{APÊNDICE I}

\section{Questionário}

Prezado Sr (a).

Pedimos a colaboração de todos, para que possam responder ao questionário que iremos apresentar ao Mercado Triunfo.

\begin{tabular}{|c|c|c|c|c|c|c|}
\hline 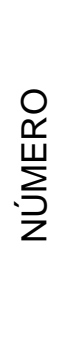 & $\sum_{\underset{E}{W}}^{\mathcal{N}}$ & 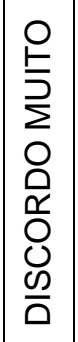 & 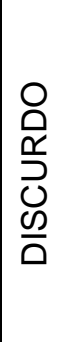 & 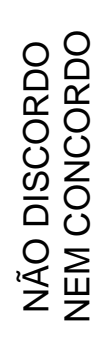 & $\begin{array}{l}0 \\
0 \\
0 \\
0 \\
0 \\
\text { Ż } \\
0 \\
0\end{array}$ & 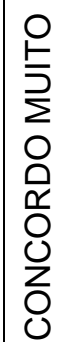 \\
\hline 01 & É fácil achar os produtos que preciso no mercado Triunfo & & & & & \\
\hline 02 & $\begin{array}{l}\text { No Mercado Triunfo o espaço entre os caixas e as prateleiras } \\
\text { é amplo para receber os seus clientes. }\end{array}$ & & & & & \\
\hline 03 & O Mercado Triunfo oferece boa variedade de produtos & & & & & \\
\hline 04 & Os produtos do Mercado Triunfo estão bem iluminados & & & & & \\
\hline 05 & $\begin{array}{l}\text { As carnes no Mercado Triunfo estão sempre frescas, com boa } \\
\text { aparência, e possuem boa qualidade. }\end{array}$ & & & & & \\
\hline 06 & $\begin{array}{l}\text { Os produtos da seção de alimentos não-perecíveis do } \\
\text { Mercado Triunfo estão sempre com a validade correta. }\end{array}$ & & & & & \\
\hline 07 & $\begin{array}{l}\text { O Mercado Triunfo oferece uma variedade de produtos na sua } \\
\text { padaria }\end{array}$ & & & & & \\
\hline 08 & $\begin{array}{l}\text { Os produtos na Padaria do Mercado Triunfo são bem } \\
\text { expostos }\end{array}$ & & & & & \\
\hline 09 & $\begin{array}{l}\text { Os pães e doces do Mercado Triunfo estão sempre frescos e } \\
\text { com sabor agradável }\end{array}$ & & & & & \\
\hline 10 & $\begin{array}{l}\text { No Mercado Triunfo os equipamentos utilizados nos caixas } \\
\text { possibilitam menos erros na operação. }\end{array}$ & & & & & \\
\hline
\end{tabular}

Tabela 1 - Questionário validado, utilizado na Pesquisa de Campo.

Fonte: Prado \& Marchetti, 1997. 


\section{ANEXO I}

Questionário original validado pelo autor Mattar (1997), na pesquisa de campo.

\begin{tabular}{|c|c|c|c|c|c|c|}
\hline 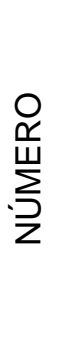 & $\underset{\underline{E}}{\stackrel{N}{E}}$ & $\begin{array}{l}0 \\
\stackrel{5}{D} \\
\sum \\
0 \\
0 \\
\frac{1}{1} \\
0 \\
0 \\
\frac{01}{0}\end{array}$ & 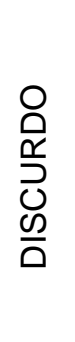 & 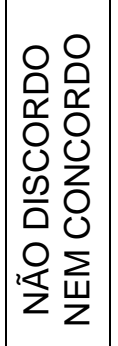 & 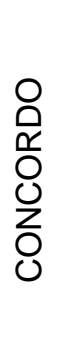 & 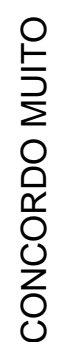 \\
\hline 01 & É fácil achar os produtos que preciso no Supermercado $X$ & & & & & \\
\hline 02 & $\begin{array}{l}\text { No Supermercado } X \text { o espaço entre os caixas e as prateleiras } \\
\text { é amplo para receber os seus clientes. }\end{array}$ & & & & & \\
\hline 03 & O ambiente do Supermercado $X$ é bem arejado e ventilado. & & & & & \\
\hline 04 & O Supermercado $X$ oferece boa variedade de produtos & & & & & \\
\hline 05 & $\begin{array}{l}\text { Os produtos que os clientes procuram estão sempre } \\
\text { disponíveis nas prateleiras do Supermercado X }\end{array}$ & & & & & \\
\hline 06 & Os produtos do Supermercado $\mathrm{X}$ estão bem iluminados & & & & & \\
\hline 07 & No Supermercado $X$ existem caixas rápidos & & & & & \\
\hline 08 & $\begin{array}{l}\text { As Diferenças entre os caixas no Supermercado X estão } \\
\text { claramente comunidade ao cliente. }\end{array}$ & & & & & \\
\hline 09 & $\begin{array}{l}\text { As carnes no Supermercado } X \text { estão sempre frescas, com } \\
\text { boa aparência, e possuem boa qualidade. }\end{array}$ & & & & & \\
\hline 10 & $\begin{array}{l}\text { Os atendentes dos caixas do Supermercado X são simpáticos } \\
\text { e prestativos }\end{array}$ & & & & & \\
\hline 11 & $\begin{array}{l}\text { Os produtos da seção de alimentos não-perecíveis do } \\
\text { Supermercado X estão sempre com a validade correta. }\end{array}$ & & & & & \\
\hline 12 & $\begin{array}{l}\text { No Supermercado } X \text { os equipamentos dos caixas permitem } \\
\text { que as filas sejam rápidas }\end{array}$ & & & & & \\
\hline 13 & $\begin{array}{l}\text { O Supermercado } X \text { oferece uma variedade de produtos na } \\
\text { sua padaria }\end{array}$ & & & & & \\
\hline 14 & $\begin{array}{l}\text { Os produtos na Padaria do Supermercado X são bem } \\
\text { expostos }\end{array}$ & & & & & \\
\hline 15 & $\begin{array}{l}\text { Os pães e doces do Supermercado Triunfo estão sempre } \\
\text { frescos e com sabor agradável }\end{array}$ & & & & & \\
\hline 16 & $\begin{array}{l}\text { A validade dos produtos da seção de frios do Supermercado } \\
X \text { está sempre em dia }\end{array}$ & & & & & \\
\hline 17 & $\begin{array}{l}\text { Os produtos e os preços na seção de frios estão bem } \\
\text { expostos no Supermercado } X\end{array}$ & & & & & \\
\hline
\end{tabular}


\begin{tabular}{|l|l|l|l|l|l|} 
& $\begin{array}{l}\text { No Supermercado X os equipamentos utilizados nos caixas } \\
\text { possibilitam menos erros na operação. }\end{array}$ & & & & \\
\hline $19 \begin{array}{l}\text { No Supermercado X existem pessoas bem preparadas e com } \\
\text { boa vontade para fornecer informações. }\end{array}$ & & & & & \\
\hline
\end{tabular} Tabela 2 - Questionário validado, utilizado na Pesquisa de Campo.

Fonte: Prado \& Marchetti, 1997. 